\title{
Economen op de arbeidsmarkt 1997 : WO-monitor economie
}

Citation for published version (APA):

Welters, R. A. M. H. M., Willems, E., \& van der Velden, R. K. W. (1999). Economen op de arbeidsmarkt 1997 : WO-monitor economie. Researchcentrum voor Onderwijs en Arbeidsmarkt, Faculteit der Economische Wetenschappen. ROA Reports No. 2 https://doi.org/10.26481/umarep.1999002

Document status and date:

Published: 01/01/1999

DOI:

10.26481/umarep.1999002

Document Version:

Publisher's PDF, also known as Version of record

\section{Please check the document version of this publication:}

- A submitted manuscript is the version of the article upon submission and before peer-review. There can be important differences between the submitted version and the official published version of record.

People interested in the research are advised to contact the author for the final version of the publication, or visit the DOI to the publisher's website.

- The final author version and the galley proof are versions of the publication after peer review.

- The final published version features the final layout of the paper including the volume, issue and page numbers.

Link to publication

\footnotetext{
General rights rights.

- You may freely distribute the URL identifying the publication in the public portal. please follow below link for the End User Agreement:

www.umlib.nl/taverne-license

Take down policy

If you believe that this document breaches copyright please contact us at:

repository@maastrichtuniversity.nl

providing details and we will investigate your claim.
}

Copyright and moral rights for the publications made accessible in the public portal are retained by the authors and/or other copyright owners and it is a condition of accessing publications that users recognise and abide by the legal requirements associated with these

- Users may download and print one copy of any publication from the public portal for the purpose of private study or research.

- You may not further distribute the material or use it for any profit-making activity or commercial gain

If the publication is distributed under the terms of Article $25 \mathrm{fa}$ of the Dutch Copyright Act, indicated by the "Taverne" license above, 


\section{Economen op de arbeidsmarkt 1997 WO-Monitor Economie}

ROA-R-1999/2

R.A.M.H.M. Welters
E.J.T.A. Willems
R.K.W. van der Velden

Researchcentrum voor Onderwijs en Arbeidsmarkt

Faculteit der Economische Wetenschappen

Universiteit Maastricht

Maastricht, september 1998 
ISBN 90-5321-249-3

Sec98.128/RW 


\section{Inhoud}

Bladzijde

Voorwoord i

Samenvatting $\quad$ iii

$\begin{array}{ll}1 \text { TInleiding } & 1\end{array}$

2 Zoekgedrag, werkgelegenheid en werkzekerheid 5

2.1 Zoekgedrag 5

$\begin{array}{ll}2.2 \text { Werkgelegenheid en werkzekerheid } & 10\end{array}$

3 Kwaliteit van het werk 13

$\begin{array}{ll}3.1 \text { Aansluiting opleiding-werk } & 13\end{array}$

$\begin{array}{ll}3.2 \text { Andere kwalitatieve aspecten van het werk } & 16\end{array}$

4 Economen op de arbeidsmarkt voor HBO'ers 23

4.1 Andere mensen? 24

4.2 Andere banen? 26

4.3 Universitaire studie na HBO-opleiding: zinvolle investering? 29

4.4 Gevolgen voor het curriculum? 31

$\begin{array}{ll}\text { Literatuur } & 35\end{array}$

Bijlage? Bepaling van 'on-the-job' en 'off-the-job' zoekgedrag 37 
$\ldots \ldots$ 


\section{Voorwoord}

In opdracht van de economische faculteiten van de Erasmus Universiteit Rotterdam (EUR), de Katholieke Universiteit Brabant (KUB), de Universiteit van Amsterdam (UvA), de Vrije Universiteit (VU) en het College van Bestuur van de Universiteit Maastricht (UM) is eind 1996 - begin 1997 voor de vierde keer de WO-monitor economie uitgevoerd. Dit betekent dat de WO-Monitor economie thans vrijwel alle pas afgestudeerde economen omvat. Alleen de afgestudeerden van de Rijksuniversiteit Groningen zitten nog niet in de enquête. Vanaf volgend jaar worden met de landelijke invoering van de WO-Monitor in VSNU-verband ook deze afgestudeerde economen geënquêteerd, zodat er een compleet landelijk beeld van de afgestudeerde universitaire economen kan worden geschetst.

Het onderzoeksproject is gericht op het in kaart brengen van de arbeidsmarktintrede van afgestudeerde economen. Daartoe wordt jaarlijks een schriftelijke enquête gehouden in de maanden oktober-januari onder alle afgestudeerden van het daaraan voorafgaande jaar, hetgeen neerkomt op zo'n anderhalf jaar na het afstuderen (afhankelijk van de maand waarin men is afgestudeerd en de maand waarin men de vragenlijst heeft ingevuld). De enquête geeft aldus informatie over de startfuncties van de afgestudeerden. De gehanteerde vragenlijst bevat vragen over de persoon, de afgesloten opleiding, de vooropleiding, de eventuele werk- en bestuurservaring vóór het afstuderen, de belangrijkste activiteiten na het afstuderen tot het moment van enquêteren, de huidige arbeidsmarktpositie, eventueel gevolgd onderwijs na het afstuderen en - bij betaald werkenden - kenmerken van de huidige functie en van de organisatie waarin men werkzaam is, alsmede vragen over de aansluiting van de genoten opleiding op de beroepspraktijk. De definitie en classificatie van de variabelen sluit waar mogelijk aan bij de gangbare indelingen die worden gehanteerd door het Centraal Bureau voor de Statistiek (CBS).

In het vierde uitvoeringsjaar, eind 1997/begin 1998, zijn alle economen schriftelijk benaderd, die een getuigschrift hebben behaald bij één van de eerste faseopleidingen van:

- de Faculteit der Economische Wetenschappen van de EUR, de Faculteit der Economische Wetenschappen en Econometrie van de UvA en de Faculteit der Economische Wetenschappen en Econometrie van de VU, tussen begin september 1995 en eind augustus 1996;

- de Faculteit der Economische Wetenschappen van de KUB, tussen begin januari 1996 en eind december 1996;

- de Faculteit der Economische Wetenschappen en Bedrijfskunde van de UM, tussen begin oktober 1995 en eind september 1996.

Het betreft in totaal 3091 afgestudeerde economen. Na de eerste verzending van de vragenlijst is een rappel verstuurd aan de afgestudeerden die toen nog niet hadden gereageerd en is, waar nodig, een tweede schriftelijk rappel uitgevoerd. Tevens 
heeft in een aantal gevallen een telefonisch rappel plaatsgevonden. Uiteindelijk hebben 1587 afgestudeerden de vragenlijst geretourneerd, hetgeen neerkomt op een respons van $51 \%$.

Het ROA voert de WO-Monitor Economie uit in samenwerking met DESAN Marktonderzoek te Amsterdam. Het ROA heeft bij de uitvoering van het onderzoeksproject de leiding en is verantwoordelijk voor de instrumentontwikkeling, de kwaliteitsbewaking, het databeheer alsmede het thans voorliggende eindrapport. DESAN Marktonderzoek is verantwoordelijk voor de gegevensverzameling, de gegevensverwerking en het maken van de vertrouwelijke, statistische faculteitsrapportages ten behoeve van de deelnemende faculteiten.

Dit rapport is onder begeleiding van dr. R.K.W. van der Velden en drs. E.J.T.A. Willems samengesteld door drs. R.A.M.H.M. Welters. Onze dank gaat uit naar de facultaire contactpersonen voor hun commentaar op een concept-versie van deze rapportage: mevr. drs. A.G. Korevaar (KUB), mevr. drs. J.G. Westra (VU), mevr. drs. I.M. Wijk (UM), dhr. drs. W.A. van den Brink (EUR) en dhr. drs. P.L. Hilkhuysen (UvA). 


\title{
Samenvatting
}

\author{
Zoekgedrag
}

Vrijwel alle economen beschouwen de afgesloten universitaire opleiding als hun eind-opleiding. $\mathrm{Na}$ afronding van deze opleiding gaan ze op zoek naar een betaalde baan. Gemiddeld genomen bedraagt de intredewerkloosheid, dit is de totale 'off-thejob' zoekduur in de intredeperiode, nog geen halve maand. Deze korte zoektijd hangt samen met het feit dat de meeste economen direct in aansluiting op hun studie werk hebben gevonden. Een groot deel zoekt overigens 'on-the-job' verder naar een (betere) baan. Deze 'on-the-job' zoektijd is aanzienlijk langer: ruim 7 maanden. Daarnaast beginnen veel hoger opgeleiden reeds voor hun afstuderen te zoeken naar werk. Economen beginnen hier gemiddeld genomen ongeveer 5 maanden van tevoren mee. De (verwachte) arbeidsmarktsituatie beïnvloedt het zoekgedrag van economen. Economen die verwachten makkelijk werk te kunnen vinden, zoeken minder intensief naar werk en wachten ook vaker af tot de in hun ogen 'ideale' vacature zich aandient. Dit laatste geldt met name voor bestuurlijk informatiekundigen en fiscaal economen.

\section{Werkgelegenheid}

Het zoekgedrag van economen mondt op dit moment vrijwel altijd uit in een betaalde functie. Mede vanwege de gunstige economische ontwikkeling vindt $98 \%$ een betaalde functie binnen anderhalf jaar na afstuderen. De werkloosheid onder pas afgestudeerde economen is daarmee nog lager dan in 1996. Alleen algemeen economen en afgestudeerden Internationaal Management (IM) vinden relatief gezien iets minder gemakkelijk werk. Het overgrote deel van deze baanvinders heeft al een vaste aanstelling of heeft daar uitzicht op. Ook zijn er nauwelijks economen die een functie hebben waarin ze minder uren kunnen werken dan ze eigenlijk zouden willen.

\section{Aansluiting opleiding-werk}

Opvallend is dat - ondanks de gunstige arbeidsmarktontwikkelingen - nog steeds ongeveer de helft van de economen een functie heeft die qua niveau en qua richting minder goed aansluit bij de gevolgde opleiding. Vooral het vinden van een functie van academisch niveau blijkt lastig te zijn voor economen. Het niet vinden van passend werk doet zich voornamelijk voor onder bestuurlijk informatiekundigen. De beloning van economen heeft zich daarentegen de afgelopen jaren wel gunstig ontwikkeld. Dit geldt vooral voor de economen van opleidingsrichtingen die er in sterkere mate in zijn geslaagd een aansluitende functie te vinden. Verder blijkt dat één op de vijf economen anderhalf jaar na afstuderen al een leidinggevende functie heeft. Vooral bedrijfskundigen vinden vaak een leidinggevende functie. Eén op de 
drie bedrijfskundigen heeft een functie met een leidinggevend karakter. Om in aanmerking te komen voor zo'n leidinggevende functie is het reeds hebben van werkervaring vaak een vereiste. Voor een dergelijke functie wordt namelijk tweemaal zo vaak werkervaring vereist als voor een niet-leidinggevende functie. Negen van de tien economen hebben reeds tijdens hun studie enige relevante werk- en/of bestuurservaring opgedaan.

\section{Economen op de arbeidsmarkt voor HBO'ers}

Ofschoon ruim $40 \%$ van de economen een functie op HBO-niveau heeft, wil dat niet zeggen dat deze economen allemaal op zoek zijn naar ander werk. Integendeel slechts één van de vijf economen met een baan op HBO-niveau is op zoek naar ander werk. De arbeidsmarkt voor economen lijkt zich daarmee te karakteriseren als een markt waar een grote substitutie tussen WO- en HBO-opgeleiden plaatsvindt. Dit laat onverlet dat er in het algemeen ruime uitwijkmogelijkheden voor economen zijn. Opmerkelijk is echter dat meer uitwijkmogelijkheden voor economische studierichtingen niet automatisch betekent dat men vaker op WO-niveau terechtkomt. Wel lijken er duidelijk verschillen in capaciteiten te zijn tussen economen werkzaam op WO-niveau en economen werkzaam op HBO-niveau. Voor WO-functies selecteren werkgevers de economen met de grootste capaciteiten. Bovendien blijken functies op HBO-niveau geen eigenschappen te hebben die zouden kunnen verklaren waarom economen een HBO-functie zouden verkiezen boven een functie op WOniveau.

Ondanks het feit dat veel WO-economen terechtkomen op een HBO-functie is het toch zinvol voor HBO-afgestudeerden om een economische WO-opleiding te gaan volgen. Ook al komen ze na afronding van deze WO-opleiding terecht in een HBOfunctie, dan nog is de beloning significant hoger dan de beloning die HBO'ers in een HBO-functie gemiddeld genomen ontvangen.

Het feit dat veel universitaire economen op HBO-niveau terechtkomen heeft ook gevolgen over hoe zij achteraf aankijken tegen hun opleiding. Economen werkzaam op WO-niveau zouden graag iets andere accenten in de opleiding willen zien dan degenen die in een HBO-functie actief zijn. Waar economen die een HBO-functie hebben gevonden meer aandacht voor praktische aspecten zouden willen hebben, zoals organisatorische, coördinerende en onderhandelingstechnieken, kiezen economen actief op WO-niveau vaker voor meer theoretische diepgang van een studie. Ook het internationale aspect van een studie wordt belangrijker ervaren door economen werkzaam op WO-niveau dan door economen werkzaam op HBO-niveau. 


\section{Inleiding}

De economen die de afgelopen tijd zijn afgestudeerd hebben onder een in het algemeen gunstig economisch gesternte de arbeidsmarkt betreden. De werkloosheid in Nederland is volgens het CBS in 1997 gedaald tot 6\%; in 1996 was dit $7 \%$. De werkloosheid onder academici is zowel in 1997 als in 1996 1\%-punt lager dan voor de totale beroepsbevolking. Waarschijnlijk heeft deze gunstige situatie zijn weerslag op de arbeidsmarktintrede en loopbaanperspectieven van pas afgestudeerde economen. Van der Linden en Van der Velden (1998) laten bijvoorbeeld zien dat het succes van de overgang van universiteit naar arbeidsmarkt, of het gebrek daaraan, ook na jaren nog doorwerkt, met name in de beloning en de mate waarin men een baan op niveau weet te verwerven.

Dit rapport beschrijft de arbeidsmarktintrede van de economen die in het studiejaar 1995/1996 zijn afgestudeerd ${ }^{1}$. Daarbij kunnen meerdere aspecten worden onderscheiden. Wellicht de belangrijkste vraag: in welke mate slagen de pas afgestudeerde economen erin om werk te vinden en hoe lang zoekt men gemiddeld naar een baan? Daarnaast spelen echter andere (baan)kenmerken een rol. Hoe zeker is de verworven baan, met andere woorden betreft het een vaste baan of slechts een kortdurend contract? Wat is de kwaliteit van de banen? Vinden de economen de baan die aansluit bij hun richting? Willen zij meer of juist minder uren per week werken? Wat verdienen zij? En hebben zij andere financiële voordelen vanuit hun functie?

Bij de beantwoording van al deze vragen zal een onderscheid worden gemaakt naar een zevental opleidingsrichtingen: bedrijfskunde, bestuurlijke informatiekunde, econometrie, algemene economie, bedrijfseconomie, fiscale economie en international management (IM). Tabel 1.1 toont per opleidingsrichting het aantal respondenten en de aandelen per richting in het totale onderzoeksbestand. De opleidingsrichting bedrijfseconomie is met ruim tweederde van de afgestudeerden veruit de grootste economische opleidingsrichting. Dit beeld komt redelijk overeen met het totaalbeeld van het aantal afgestudeerde economen in Nederland. In het totaalcijfer zitten ook nog 59 afgestudeerden die niet aan één van de zeven genoemde opleidingsrichtingen kunnen worden toebedeeld. Dit betreft met name enkele kleine opleidingsrichtingen die slechts aan één universiteit kunnen worden gevolgd. Zij worden in dit rapport wel meegenomen in het totaalcijfer.

1. Zoals aangegeven in het voorwoord gaat het bij de KUB om de afgestudeerden van het kalenderjaar 1996. 
Tabel 1.1

Verdeling respondenten naar opleidingsrichting

\begin{tabular}{lrr}
\hline Opleidingsrichting & aantal & $\%$ \\
\hline Bedrijfskunde & 40 & 3 \\
Bestuurlijke informatiekunde & 35 & 2 \\
Econometrie & 149 & 10 \\
Algemene economie & 141 & 9 \\
Bedrijfseconomie & 1.033 & 68 \\
Fiscale economie & 35 & 2 \\
International management & 38 & 3 \\
Totaal & 1.530 & 100 \\
\hline
\end{tabular}

Bron: ROA/WO-Monitor Economie 1997

\section{Achtergronden onderzoekspopulatie}

Om een beeld te krijgen van de onderzochte groep economen zijn in tabel 1.2 enkele persoonskenmerken van de respondenten weergegeven. De WO-opleiding economie is nog steeds een door mannen gedomineerde studie. Slechts $30 \%$ van de pas afgestudeerde economen is vrouw. Daarmee wordt overigens wel de stijgende lijn van de afgelopen jaren voortgezet. In 1994 was zo'n $23 \%$ van de pas afgestudeerden vrouw. Via $24 \%$ in 1995 was dat in 1996 reeds opgelopen tot $26 \%$. Bij de richting bestuurlijke informatiekunde is het percentage vrouwen met $18 \%$ het laagst.

In het onderzoeksbestand komen allochtonen vrijwel niet voor; slechts $1 \%$ van de aan de enquête deelnemende economen is van niet-Nederlandse afkomst. De gemiddelde leeftijd van de afgestudeerden, anderhalf jaar na afstuderen is ongeveer 26 jaar. De verschillen tussen de opleidingsrichtingen zijn hierbij gering. Ook ten opzichte van voorgaande jaren zijn de verschillen miniem.

Tabel 1.2

Verdeling respondenten naar geslacht, etniciteit, en gemiddelde leeftijd

\begin{tabular}{lccc}
\hline Opleidingsrichting & $\begin{array}{r}\text { vrouw } \\
\%\end{array}$ & $\begin{array}{r}\text { allochtoon } \\
\%\end{array}$ & $\begin{array}{r}\text { gemiddelde leeftijd ten } \\
\text { tijde van de enquête }\end{array}$ \\
\hline Bedrijfskunde & 40 & 0 & 26,1 \\
Bestuurlijke informatiekunde & 18 & 3 & 25,5 \\
Econometrie & 30 & 1 & 25,6 \\
Algemene economie & 29 & 3 & 26,4 \\
Bedrijfseconomie & 30 & 1 & 26,2 \\
Fiscale economie & 26 & 0 & 25,8 \\
International management & 37 & 0 & 25,7 \\
Totaal & 30 & 1 & 26,1 \\
\hline
\end{tabular}

Bron: ROA/WO-Monitor Economie 1997 
Tabel 1.3

Verdeling respondenten naar vooropleiding

\begin{tabular}{lrrr}
\hline Opleidingsrichting & $\begin{array}{r}\text { VWO } \\
\%\end{array}$ & $\begin{array}{r}\text { HBO } \\
\%\end{array}$ & $\begin{array}{r}\text { anders } \\
\%\end{array}$ \\
\hline Bedrijfskunde & 90 & 3 & 8 \\
Bestuurlijke informatiekunde & 91 & 9 & 0 \\
Econometrie & 99 & 1 & 3 \\
Algemene economie & 89 & 8 & 1 \\
Bedrijfseconomie & 78 & 4 & 0 \\
Fiscale economie & 86 & 14 & 3 \\
International management & 84 & 15 & 2 \\
Totaal & 82 & & \\
\hline
\end{tabular}

Bron: ROA/WO-Monitor Economie 1997

Vier van de vijf economen zijn rechtstreeks van het VWO doorgestroomd naar de zojuist afgesloten universitaire opleiding. Dit blijkt uit tabel 1.3. Opvallend veel bedrijfseconomen hebben een HBO-achtergrond. Dit betreft met name de HEAOdoorstromers. Econometristen hebben vaker dan gemiddeld het VWO als vooropleiding. Algemeen economen en internationaal management afgestudeerden hebben iets vaker een andere vooropleiding. Het gaat hier met name om een andere WOopleiding. Ook afgestudeerden international management hebben relatief vaak een HBO-opleiding gevolgd voorafgaand aan de economische opleiding.

Tabel 1.4

Verdeling respondenten naar studieduur

\begin{tabular}{lrrr}
\hline Opleidingsrichting & $\begin{array}{r}\text { netto studieduur } \\
\text { (jaren) }\end{array}$ & $\begin{array}{r}\text { studie } \\
\text { onderbroken } \\
\%\end{array}$ & $\begin{array}{r}\text { aantal maanden } \\
\text { studie-onderbreking }\end{array}$ \\
\hline Bedrijfskunde & 5,8 & 5 & 11 \\
Bestuurlijke informatiekunde & 5,0 & 0 & - \\
Econometrie & 5,4 & 5 & 15 \\
Algemene economie & 5,5 & 11 & 11 \\
Bedrijfseconomie & 5,2 & 7 & 3 \\
Fiscale economie & 5,1 & 3 & 12 \\
International management & 5,1 & 5 & 12 \\
Totaal & 5,2 & 6 & \\
\hline
\end{tabular}

Bron: ROA/WO-Monitor Economie 1997

In tabel 1.4 wordt vervolgens een overzicht van de gemiddelde studieduur gegeven. De economen hebben gemiddeld genomen 5,2 jaar over hun studie gedaan. Het betreft hier de netto studietijd, dus gecorrigeerd voor eventuele onderbrekingen. Bedrijfskundigen doen gemiddeld ruim een half jaar langer over hun studie. Van alle economen onderbreekt $6 \%$ de studie tussentijds om later de draad weer op te pak- 
ken en de studie af te ronden. Vooral algemeen economen doen dit relatief vaak. In het geval van een studieonderbreking blijkt die gemiddeld één jaar te duren.

Tabel 1.5 toont ten slotte de doorstroomkeuze die de economen hebben gemaakt na afloop van de studie. Het blijkt dat vrijwel alle pas afgestudeerde economen toetreden tot de arbeidsmarkt. Slechts $1 \%$ kiest een vervolgopleiding. Het vervolg van dit rapport richt zich dan ook uitsluitend op die economen die de arbeidsmarkt betreden.

Tabel 1.5

Verdeling respondenten naar bestemming na afstuderen

\begin{tabular}{|c|c|c|c|}
\hline Opleidingsrichting & $\begin{array}{r}\text { intrede } \\
\text { arbeidsmarkt } \\
\%\end{array}$ & $\begin{array}{r}\text { vervolg- } \\
\text { opleiding } \\
\%\end{array}$ & $\begin{array}{r}\text { anders } \\
\%\end{array}$ \\
\hline $\begin{array}{l}\text { Bedrijfskunde } \\
\text { Bestuurlijke informatiekunde } \\
\text { Econometrie } \\
\text { Algemene economie } \\
\text { Bedrijfseconomie } \\
\text { Fiscale economie } \\
\text { International management }\end{array}$ & $\begin{array}{l}98 \\
97 \\
97 \\
96 \\
99 \\
97 \\
97\end{array}$ & $\begin{array}{l}3 \\
3 \\
3 \\
3 \\
1 \\
3 \\
0\end{array}$ & $\begin{array}{l}0 \\
0 \\
0 \\
2 \\
0 \\
0 \\
3\end{array}$ \\
\hline Totaal & 98 & 1 & 1 \\
\hline
\end{tabular}

Bron: ROA/WO-Monitor Economie 1997

\section{Opzet rapport}

Het rapport is verder als volgt gestructureerd. In hoofdstuk 2 wordt eerst ingegaan op het zoekgedrag van economen. Daarbij wordt tevens ingegaan op de wijze van zoeken: 'off-the-job' of 'on-the-job', vóór en na afstuderen, via formele of informele kanalen. Ook het resultaat van deze baanzoekperiode komt aan de orde: de werkgelegenheid en werkzekerheid voor afgestudeerde economen. Hoofdstuk 3 gaat vervolgens in op de kwaliteit van het werk. Een belangrijk aandachtspunt is daarbij de aansluiting van de opleiding op het werk naar niveau en richting maar ook enkele andere kwaliteitspunten komen aan de orde (primaire en secundaire arbeidsvoorwaarden, leidinggeven e.d.)

In hoofdstuk 4 wordt expliciet ingegaan op een belangrijk fenomeen bij de arbeidsmarktintrede van economen. Een aanzienlijk deel blijkt terecht te komen in banen op HBO-niveau. Dit beeld wordt reeds enkele jaren geconstateerd. Er wordt gezocht naar mogelijke verklaringen voor deze mogelijke 'onderbenutting'. Ook wordt ingegaan op de vraag of de universitaire economie-opleiding een zinvolle investering is door een vergelijking te maken met economisch opgeleide HBO'ers. Tot slot wordt nagegaan of het gegeven dat veel economen in HBO-functies terechtkomen gevolgen zou moeten hebben voor de inrichting van het curriculum. 


\section{Zoekgedrag, werkgelegenheid en werkzekerheid}

Dit hoofdstuk geeft een beschrijving van de overgang van economen van de universiteit naar de arbeidsmarkt. In deze transitiefase staat het zoekgedrag centraal. Paragraaf 2.1 staat dan ook geheel in het teken van het zoekgedrag van economen. Hierbij zal onder andere worden onderzocht vanuit welke positie naar werk wordt gezocht. Zoeken de economen 'on-the-job' of 'off-the-job' naar werk? Ook het startmoment van de zoekperiode en de gevolgen daarvan komen aan bod. Paragraaf 2.2 staat in het teken van de resultaten van het zoekgedrag: naast de kans op werk komt de zekerheid van het gevonden werk ter sprake.

\subsection{Zoekgedrag}

Actief zoeken naar werk verhoogt uiteraard de kans op het daadwerkelijk vinden van werk, maar het brengt ook kosten met zich mee. Vanuit de standaard 'job search' theorie (zie bijvoorbeeld Mortensen, 1986) kan worden beargumenteerd dat een individu zoekkosten zal maken zolang deze de verwachte opbrengsten (verwachte verdisconteerde beloning in een gewenste baan) niet overtreffen. De kosten van zoeken bestaan niet alleen uit directe kosten (bijvoorbeeld informatie zoeken), maar ook uit indirecte kosten in de vorm van niet-gerealiseerde beloningen. De tijd die het individu spendeert aan het zoeken naar werk, kan hij immers niet meer gebruiken om te gaan werken.

\section{On-the-job/off-the-job}

Voor hoger opgeleiden, kan er een extra dimensie aan het zoekproces worden toegevoegd. Hun hoge opleidingsniveau en in het specifieke geval van economen de relatief generalistische opleiding, stelt ze in staat om vrij gemakkelijk een baan te vinden waarvoor een lager opleidingsniveau vereist is. Economen kunnen dus de keuze maken tussen 'off-the-job' of 'on-the-job' zoeken naar een gewenste baan. 'Off-the-job' zoeken heeft als voordeel dat de zoekintensiteit maximaal kan zijn, maar de periode dat er gezocht kan worden is beperkt, want er zijn geen of slechts lage opbrengsten in die periode. 'On-the-job' zoeken zal in het algemeen een lagere zoekintensiteit met zich mee brengen. De econoom werkt immers. De zoekperiode kan wel vrij lang zijn, want hij genereert opbrengsten (loon) tijdens zijn zoekproces.

'On-the-job/off-the-job' zoekgedrag heeft niet alleen gevolgen voor de zoekintensiteit en de potentiële duur van de zoekperiode, het kan ook gevolgen hebben voor het rendement van een zoekactie. Werkgevers kunnen 'witte vlekken' in een CV als een negatief kenmerk van de werkzoekenden beschouwen. Een langdurige werkloosheidsperiode kan door een werkgever als een negatief signaal worden geïnterpreteerd omtrent iemands productieve vaardigheden. Volgens Meager en Metcalf 
(1987) speelt dit vooral bij hoger opgeleiden een rol. Het rendement van 'off-the-job' zoekgedrag zal daarom na verloop van tijd snel afnemen.

Tabel 2.1 geeft een overzicht van het aantal maanden in de transitieperiode dat economen 'on-the-job' zoeken naar werk en het aantal maanden dat ze 'off-the-job' naar een baan zoeken. On-the-job zoekgedrag is geoperationaliseerd als het aantal maanden dat een econoom een functie heeft, van waaruit hij op zoek is naar een andere functie (zie bijlage 1 voor de exacte definitie van 'on-the-job' zoekgedrag). Op het moment dat hij niet meer zoekt naar een andere functie is het zoekproces ten einde en wordt er dus ook niet meer 'on-the-job' gezocht. 'Off-the-job' zoekgedrag is geoperationaliseerd als het aantal maanden dat een econoom zoekt naar werk vanuit een werkloze arbeidsmarktpositie.

Tabel 2.1

'On-the-job/off-the-job' zoekgedrag tijdens de intredeperiode

\begin{tabular}{lrrr}
\hline Opleidingsrichting & $\begin{array}{c}\text { 'on-the-job' } \\
\text { zoekgedrag } \\
\text { in maanden }\end{array}$ & $\begin{array}{r}\text { 'off-the-job' } \\
\text { zoekgedrag } \\
\text { in maanden }\end{array}$ & totaal \\
in maanden
\end{tabular}

Bron: ROA/WO-Monitor Economie 1997

Het blijkt dat economen gemiddeld genomen ruim zeven maanden van de eerste anderhalf jaar na afstuderen gebruiken om te zoeken naar een geschikte functie. We wijzen erop dat het hier gepresenteerde totaalcijfer niet opgevat kan worden als de totale zoekduur. Van degenen die op het enquêtemoment werkloos zijn of vanuit een baan nog zoeken naar ander werk, is immers niet bekend hoe lang zij nog zullen zoeken. We spreken in dit geval van 'rechtse censurering'. Het hier gepresenteerde totaalcijfer betekent daardoor een onderschatting van de totale zoektijd. Wel moet worden beseft dat de zoekintensiteit van 'on-the-job' zoeken waarschijnlijk lager is dan die van 'off-the-job' zoeken. Het is zelfs mogelijk dat de afgestudeerden in een tussenliggende periode helemaal niet heeft gezocht.

Bestuurlijk informatiekundigen, econometristen en fiscaal economen vinden relatief snel een geschikte baan. Algemeen economen en IM'ers doen er relatief langer over. De gemiddelde zoektijd 'on-the-job' is aanmerkelijk langer dan de gemiddelde zoekduur 'off-the-job'. Gemiddeld bedraagt de zoektijd 'on-the-job' ruim 7 maanden, terwijl de zoekduur 'off-the-job' 2 weken duurt. Bestuurlijk informatiekundigen, eco- 
nometristen en fiscaal economen zoeken vrijwel nooit 'off-the-job'. Dit in tegenstelling tot algemeen economen die gemiddeld ruim één maand 'off-the-job' zoeken.

\section{Zoeken tijdens de studie}

Naast het 'on-the-job' zoeken en het 'off-the-job' zoeken na afstuderen, beginnen veel economen al tijdens hun studie met het zoeken naar werk. Op deze manier blijven de zoekkosten beperkt en kunnen werkloosheidsperioden wellicht worden vermeden. Tabel 2.2 geeft aan in hoeverre ze voor hun afstuderen reeds op zoek gaan naar werk.

Tabel 2.2

Zoekgedrag voor beëindiging van de studie

\begin{tabular}{lcc}
\hline Opleidingsrichting & $\begin{array}{c}\text { actief zoeken voor } \\
\text { einde studie } \\
\%\end{array}$ & $\begin{array}{c}\text { gemiddeld aantal } \\
\text { maanden voor } \\
\text { einde studie }\end{array}$ \\
\hline Bedrijfskunde & 89 & 5,9 \\
Bestuurlijke informatiekunde & 89 & 4,4 \\
Econometrie & 78 & 5,1 \\
Algemene economie & 72 & 5,7 \\
Bedrijfseconomie & 74 & 5,4 \\
Fiscale economie & 86 & 6,1 \\
International management & 67 & 4,4 \\
Totaal & 75 & 5,4 \\
\hline
\end{tabular}

Bron: ROA/WO-Monitor Economie 1997

Driekwart van de economen die actief gezocht hebben naar een functie is daar al voor het einde van de studie mee begonnen. Afgestudeerden van de opleidingsrichtingen algemene economie, bedrijfseconomie en international management beginnen relatief minder vaak met zoeken voor afronding van de studie. De rechterkolom van tabel 2.2 geeft het aantal maanden weer dat economen voor afronding van de studie zijn begonnen met zoeken naar werk. Gemiddeld genomen start men ruim vijf maanden voor afstuderen met het zoekproces. Van degenen die ten minste 3 maanden voor het einde van de studie is begonnen met het zoeken naar werk heeft $83 \%$ een baan gevonden direct in aansluiting op de studie. Met name voor bedrijfseconomen is het van belang om vroeg te beginnen met het zoeken naar werk. Van hen is - mits ze minstens drie maanden voor afstuderen beginnen met het zoeken $-83 \%$ niet werkloos geweest, terwijl slechts $54 \%$ van de bedrijfseconomen die minder dan 3 maanden voor afstuderen zijn begonnen met zoeken naar werk nooit werkloos is geweest. 


\section{Verwachte arbeidsmarktsituatie}

De zoekstrategie die afgestudeerden hanteren hangt mede af van de arbeidsmarktsituatie waarbinnen zij moeten opereren. Economen die gezien de arbeidsmarktsituatie verwachten snel een gewenste baan te kunnen vinden, zullen sneller geneigd zijn om laat te beginnen met zoeken naar werk. Ook zal men eerder 'off-thejob' zoeken dan economen die verwachten niet snel een gewenste baan te vinden. Ook de beloning in de verwachte functie is van invloed op het zoekgedrag van economen. Verwacht men veel te gaan verdienen dan kan men het zich permitteren om hogere zoekkosten te maken, bijvoorbeeld in de vorm van 'off-the-job' zoekgedrag of door een minder intensief zoekgedrag dat resulteert in een lange zoekduur. Goede perspectieven op de arbeidsmarkt en een hoge verwachte beloning voorspellen dus dat men afwachtend zal zijn met het accepteren van een baan die niet als ideaal wordt beschouwd. Verwacht mag worden dat in zo'n situatie afgestudeerden pas 'toeslaan' op het moment dat een in hun ogen goede vacature zich aandient. In tabel 2.3 zijn beide factoren weergegeven.

Als indicator voor een goede verwachte arbeidsmarktsituatie wordt het percentage werkzame economen genomen dat niet-actief heeft gezocht naar werk. Personen die een goede arbeidsmarktsituatie verwachten zullen immers minder geneigd zijn om actief te zoeken naar werk. De verwachte beloning wordt afgemeten aan de beloning van economen die een baan hebben en niet meer op zoek zijn naar ander werk. Blijkbaar hebben zij hun gewenste arbeidsmarktpositie bereikt. Het blijkt dat $12 \%$ van alle economen niet actief gezocht heeft naar werk tijdens of na afstuderen ${ }^{2}$. Bestuurlijk informatiekundigen, econometristen en fiscaal economen zoeken duidelijk minder vaak actief naar werk dan de andere economen. De tabel laat verder zien dat vooral bedrijfskundigen en IM'ers hoge beloningen mogen verwachten. Dit betekent dat voor hen de verwachte opbrengsten bij verder zoeken hoger zijn dan gemiddeld, hetgeen zou resulteren in een langere verwachte zoekduur. Dit lijkt enigszins bevestigd te worden door de cijfers in tabel 2.1. Bestuurlijk informatiekundigen en algemeen economen zitten daarentegen duidelijk onder de gemiddelde verwachte beloning van economen. Bij de algemeen economen blijkt de relatie tussen verwachte opbrengsten en zoekduur niet op te gaan, aangezien zij de langste 'off-the-job' zoekduur kennen.

De rechterkolom van tabel 2.3 geeft het percentage economen dat na afstuderen slechts één baan heeft gehad, terwijl men niet verder zoekt naar een andere baan. Dit kan worden gezien als het percentage afgestudeerden waarvoor de eerste baan tevens de gewenste baan is. Verwacht mag worden dat studierichtingen waarvan

2. Van de economen die niet actief hebben gezocht zijn negen van de tien nooit werkloos geweest in hun intredeperiode. Van degenen die wel actief gezocht hebben, is tweederde nooit werkloos geweest. 
een hoog percentage afgestudeerden niet of nauwelijks gezocht heeft naar werk, ook hier naar voren komen met hoge percentages. Dat blijkt ook het geval. Bestuurlijk informatiekundigen, econometristen en fiscaal economen hebben relatief vaak slechts één functie bekleed in hun transitiefase. Ze zoeken niet meer naar een andere functie. Economen die nog relatief vaak actief verder zoeken, zoals bedrijfskundigen, algemeen economen en IM'ers, wachten meestal niet af tot de ideale baan zich aandient. Ze nemen in de tussentijd vaak een niet-passende baan om van daaruit verder te zoeken naar een gewenste baan.

Tabel 2.3

Indicatoren verwachte arbeidsmarktsituatie

\begin{tabular}{lclc}
\hline Opleidingsrichting & $\begin{array}{c}\text { niet-actief gezocht } \\
\text { naar werk } \\
\%\end{array}$ & $\begin{array}{l}\text { beloning in } \\
\text { gewenste baan } \\
\text { guldens }\end{array}$ & $\begin{array}{c}\text { eerste baan is } \\
\text { de goede } \\
\%\end{array}$ \\
\hline Bedrijfskunde & 10 & 4.590 & 42 \\
Bestuurlijke informatiekunde & 26 & 4.120 & 71 \\
Econometrie & 23 & 4.220 & 58 \\
Algemene economie & 9 & 4.020 & 39 \\
Bedrijfseconomie & 10 & 4.270 & 46 \\
Fiscale economie & 17 & 4.300 & 58 \\
International management & 8 & 4.430 & 29 \\
Totaal & 12 & 4.270 & 47 \\
\hline
\end{tabular}

Bron: ROA/WO-Monitor Economie 1997

\section{Vindkanalen}

Naast de intensiteit waarmee en de positie van waaruit economen zoeken, verschillen ook de kanalen die pas afgestudeerde economen aanboren om een baan te vinden. We onderscheiden hier twee categorieën, te weten zoeken via formele kanalen en zoeken via informele kanalen. Onder formele kanalen wordt hier verstaan het zoeken via het arbeidsbureau, uitzendbureau, open sollicitaties en personeelsadvertenties. Informele kanalen omvatten het zoeken van een baan via relaties die afgestudeerden hebben opgedaan tijdens hun studie en bijvoorbeeld hun stage of contacten in hun vriendenkring. Tabel 2.4 geeft een overzicht van de zoekkanalen die door economen succesvol zijn benut. Tweederde van de economen vindt een baan via formele kanalen, waarvan iets minder dan de helft via advertenties. Er is slechts één opleidingsrichting die hier grote verschillen vertoont ten opzichte van het gemiddelde en dat is de opleiding econometrie. Econometristen vinden vaak een baan via informele kanalen. Als zij al een baan vinden via formele kanalen dan doen ze dat vaker via personeelsadvertenties. Een belangrijk informeel kanaal van econometristen betreft een baan via de eigen universiteit. Vaak zijn deze econometristen werkzaam als assistent in opleiding (AIO) of als beurspromovendus. 
Tabel 2.4

Vindkanalen

\begin{tabular}{|c|c|c|c|}
\hline Opleidingsrichting & $\begin{array}{c}\text { formeel } \\
\%\end{array}$ & $\begin{array}{c}\text { (waarvan } \\
\text { advertenties) } \\
\%\end{array}$ & $\begin{array}{c}\text { informeel } \\
\%\end{array}$ \\
\hline $\begin{array}{l}\text { Bedrijfskunde } \\
\text { Bestuurlijke informatiekunde } \\
\text { Econometrie } \\
\text { Algemene economie } \\
\text { Bedrijfseconomie } \\
\text { Fiscale economie } \\
\text { International management }\end{array}$ & $\begin{array}{l}68 \\
62 \\
49 \\
60 \\
70 \\
61 \\
64\end{array}$ & $\begin{array}{l}32 \\
18 \\
25 \\
24 \\
27 \\
21 \\
26\end{array}$ & $\begin{array}{l}32 \\
38 \\
51 \\
40 \\
31 \\
39 \\
37\end{array}$ \\
\hline Totaal & 65 & 26 & 35 \\
\hline
\end{tabular}

Bron: ROA/WO-Monitor Economie 1997

\subsection{Werkgelegenheid en werkzekerheid}

De economische groei van het afgelopen jaar en de daaruit voortvloeiende aantrekkende werkgelegenheid op de arbeidsmarkt hebben hun uitwerking op de arbeidsmarktpositie van economen niet gemist. Tabel 2.5 geeft het percentage economen dat behoort tot de werkloze beroepsbevolking. Het gemiddelde werkloosheidspercentage onder pas afgestudeerde economen is met $2 \%$ uitzonderlijk laag. Omdat normaal gesproken de werkloosheid onder de intreders op de arbeidsmarkt iets hoger ligt dan de gemiddelde werkloosheid, kan met recht gesproken worden van een gespannen situatie op de arbeidsmarkt voor economen. De daling van het werkloosheidspercentage van $4 \%$ in 1996 naar $2 \%$ in 1997 is overigens wel in lijn met de daling van de werkloosheid die op andere opleidingsniveaus waar te nemen valt (zie ROA, 1998). Deze daling van het werkloosheidspercentage is nog opmerkelijker als in ogenschouw wordt genomen dat in 1994 de werkloosheid onder economen nog $10 \%$ bedroeg.

De opleidingsrichtingen algemene economie en international management kennen een hoger dan gemiddeld werkloosheidspercentage. Ook vorig jaar hadden deze twee opleidingsrichtingen het hoogste werkloosheidspercentage. Vrijwel alle afgestudeerden van de opleidingsrichtingen bestuurlijke informatiekunde en fiscale economie die zich hebben aangeboden op de arbeidsmarkt, hebben betaald werk gevonden. Wanneer een uitsplitsing wordt gemaakt naar geslacht dan blijkt dat vrouwen in het algemeen een iets grotere kans op werk hebben dan mannen. Hierop vormt de opleidingsrichting algemene economie een uitzondering. Van de vrouwelijke afgestudeerden algemene economie is $11 \%$ na anderhalf jaar werkloos.

Het lage werkloosheidspercentage kan op twee manieren worden genuanceerd. Ten eerste kan het voorkomen dat werkenden een part-time functie hebben minder dan 32 uur per week, maar liever meer uren per week zouden willen werken (werken in 
onvrijwillige deeltijd). Ze zijn dan wel niet werkloos, maar worden toch belemmerd in hun arbeidsmarktparticipatie. Tabel 2.6 toont het aandeel van economen met een onvrijwillige deeltijdaanstelling. Het blijkt dat $6 \%$ van alle werkende economen onvrijwillig een deeltijdbaan bekleedt. Onvrijwillige deeltijd speelt overigens slechts bij enkele opleidingen. Vooral onder algemeen economen is het een niet onaanzienlijk probleem. Bijna één op de tien algemeen economen werkt onvrijwillig in deeltijd.

Tabel 2.5

Werkloosheidspercentage naar geslacht en vergelijking 1996-1997

\begin{tabular}{|c|c|c|c|c|}
\hline Opleidingsrichting & $\underset{\%}{\operatorname{man}}$ & $\begin{array}{r}\text { vrouw } \\
\%\end{array}$ & $\begin{array}{r}\text { totaal } 1997 \\
\%\end{array}$ & $\begin{array}{r}\text { totaal } 1996 \\
\%\end{array}$ \\
\hline Bedrijfskunde & 4 & 0 & 3 & 3 \\
\hline Bestuurlijke informatiekunde & 0 & $X$ & 0 & 5 \\
\hline Econometrie & 1 & 0 & 1 & 4 \\
\hline Algemene economie & 1 & 11 & 4 & 6 \\
\hline Bedrijfseconomie & 2 & 1 & 1 & 3 \\
\hline Fiscale economie & 0 & $\mathrm{X}$ & 0 & 0 \\
\hline International management & 4 & $x$ & 5 & 7 \\
\hline Totaal & 1 & 2 & 2 & 4 \\
\hline
\end{tabular}

$\mathrm{X}=$ te weinig waarnemingen

Bron: ROA/WO-Monitor Economie 1996 en 1997

Ten tweede is een hoge kans op werk niet noodzakelijkerwijs synoniem aan een grote werkzekerheid voor de economen. De werkzekerheid van een functie kan onder meer worden bepaald aan de hand van de aanstellingsduur van het contract: betreft het hier een tijdelijke dan wel een vaste aanstelling. Tabel 2.6 geeft ook hiervan een overzicht. Na anderhalf jaar blijkt tweederde van de economen, die een betaalde functie hebben, een vast contract te hebben verworven. Nog eens een kwart heeft naar eigen zeggen uitzicht op een vast contract. Met andere woorden bijna alle economen die een betaalde functie hebben, hebben een vast contract of hebben daar bij hun huidige werkgever uitzicht op.

Algemeen economen hebben relatief minder vaak een vaste aanstelling. lets minder dan de helft van de algemeen economen heeft een vaste aanstelling, daarmee blijven zij achter bij het gemiddelde. Ook wanneer bij de algemeen economen het percentage met uitzicht op een vaste functie wordt opgeteld bij het percentage met een vaste baan blijken ze relatief vaak werkzaam te zijn in een tijdelijk dienstverband. Dit laatste geldt overigens ook voor econometristen. Voor een belangrijk deel wordt dit veroorzaakt door de economen die als AlO werkzaam zijn. Vooral degenen die een econometrische of algemeen economische opleiding hebben gevolgd kiezen relatief vaak voor het AIO-schap. Zij hebben per definitie een tijdelijke aanstelling. 
Tabel 2.6

Aanstellingsduur van de functie

\begin{tabular}{lccc}
\hline Opleidingsrichting & $\begin{array}{c}\text { onvrijwillige deeltijd } \\
\text { ( vaste aanstelling }\end{array}$ & $\begin{array}{c}\text { uitzicht op } \\
\text { vaste aanstelling } \\
\%\end{array}$ \\
\hline Bedrijfskunde & 5 & $\%$ & 29 \\
Bestuurlijke informatiekunde & 3 & 69 & 9 \\
Econometrie & 4 & 91 & 16 \\
Algemene economie & 9 & 72 & 35 \\
Bedrijfseconomie & 6 & 68 & 26 \\
Fiscale economie & 0 & 61 & 32 \\
International management & 0 & 54 & 43 \\
Totaal & 6 & 67 & 26 \\
\hline
\end{tabular}

Bron: ROA/WO-Monitor Economie 1997 


\section{Kwaliteit van het werk}

Zoals het vorige hoofdstuk heeft laten zien, heeft de economische hoogconjunctuur er toe bijgedragen dat het vinden van werk op dit moment voor pas afgestudeerde economen nauwelijks een probleem is. Het feit dat economen makkelijk werk vinden, hoeft echter niet automatisch te betekenen dat ze ook kwalitatief goed werk vinden. Wellicht slagen economen van bepaalde afstudeerrichtingen er makkelijker in een kwalitatief goede baan te vinden dan afgestudeerden met een andere opleidingsrichting. De kwaliteit van het gevonden werk staat centraal in dit hoofdstuk. Het kwalitatieve aspect van een functie kan van twee kanten worden belicht. Ten eerste is er de aansluiting tussen het gevonden werk en de afgeronde opleiding. Het gaat hier om de vraag of economen een functie hebben gevonden die qua niveau en richting past bij de genoten opleiding. Daarnaast spelen enkele andere aspecten een rol bij de beoordeling van het kwalitatieve niveau van een functie. De beloning, secundaire arbeidsvoorwaarden, het aantal arbeidsuren en de mate waarin men een leidinggevende functie weet te verwerven zijn zulke factoren. Een passende functie biedt geen garantie op bijvoorbeeld een hoge beloning. De hier genoemde kwalitatieve aspecten hoeven dus niet noodzakelijkerwijs overeen te stemmen met de mate van aansluiting tussen de opleiding en de gevonden functie.

\subsection{Aansluiting opleiding-werk}

De aansluiting tussen de afgesloten opleiding en de gevonden baan geeft een indicatie van de benutting van de capaciteiten van de afgestudeerden. Economen die actief zijn in een functie waarvoor een niet-academische opleiding werd vereist, lopen het risico de in de studie opgebouwde capaciteiten niet voldoende te benutten. Hier kan dus sprake zijn van onderbenutting, waarbij specifieke kennis wel aanwezig is, maar niet gebruikt wordt. Het begrip passende functie wordt hier bepaald aan de hand van twee factoren, te weten aansluiting naar niveau (betreft het een functie op academisch niveau) en aansluiting naar richting (betreft het een functie die aansluit op de opleidingsrichting). Ook de mate van aansluiting kan op twee manieren worden beoordeeld. Enerzijds kan gekeken worden naar de eisen die de werkgever stelt bij het vervullen van de vacature. Anderzijds kan de beoordeling van de economen zelf worden meegenomen wat betreft de aansluiting tussen opleiding en werk.

\section{Aansluiting naar niveau}

Gemiddeld genomen vindt iets meer dan de helft van de economen na anderhalf jaar een baan waarvoor door de werkgever een academische opleiding werd vereist. De eerste twee kolommen van tabel 3.1 geven hiervan een overzicht. De verschillen tussen opleidingsrichtingen zijn echter groot. Het blijkt derhalve van belang welke opleidingsrichting men gevolgd heeft voor het vinden van werk dat qua niveau 
aansluit bij de genoten opleiding. Vier van de vijf econometristen en fiscalisten hebben zo'n anderhalf jaar na afstuderen een baan waarvoor een academische opleiding werd vereist. Dit geldt slechts voor de helft van alle bedrijfskundigen en bedrijfseconomen, terwijl slechts iets meer dan één op de drie bestuurlijk informatiekundigen een baan op WO-niveau vindt. De inschatting van de economen zelf is dat werkgevers soms een iets hoger opleidingsniveau vereisen dan strikt voor de inhoud van het werk noodzakelijk is. Dit zou een aanwijzing kunnen zijn voor het bestaan van diploma-inflatie (zie Wolbers, 1998). Van de afgestudeerden zelf vindt $48 \%$ dat hun werk van academisch niveau is, terwijl dat academisch niveau wel in $54 \%$ van de gevallen door de werkgever vereist werd. Vooral bedrijfskundigen en IM'ers ervaren dat werkgevers een academisch opleidingsniveau vereisen voor een functie waarvoor dat volgens de afgestudeerden zelf niet nodig is.

Tabel 3.1

Aansluiting opleiding-werk

\begin{tabular}{|c|c|c|c|c|c|c|}
\hline \multirow[t]{2}{*}{ Opleidingsrichting } & \multicolumn{2}{|c|}{$\begin{array}{c}\text { op eigen } \\
\text { niveau }\end{array}$} & \multicolumn{2}{|c|}{$\begin{array}{l}\text { binnen eigen } \\
\text { verwante richting }\end{array}$} & \multicolumn{2}{|c|}{$\begin{array}{l}\text { binnen eigen } \\
\text { verwante richting } \\
\text { én op eigen niveau }\end{array}$} \\
\hline & $\begin{array}{c}\text { werkg. } \\
\%\end{array}$ & $\begin{array}{c}\text { resp. } \\
\%\end{array}$ & $\begin{array}{c}\text { werkg. } \\
\%\end{array}$ & resp. & $\begin{array}{c}\text { werkg. } \\
\%\end{array}$ & $\begin{array}{c}\text { resp. } \\
\%\end{array}$ \\
\hline Bedrijfskunde & 51 & 39 & 70 & 79 & 43 & 34 \\
\hline Bestuurlijke informatiekunde & 35 & 29 & 88 & 91 & 30 & 24 \\
\hline Econometrie & 77 & 75 & 85 & 86 & 68 & 70 \\
\hline Algemene economie & 61 & 53 & 62 & 62 & 49 & 42 \\
\hline Bedrijfseconomie & 49 & 44 & 78 & 83 & 41 & 39 \\
\hline Fiscale economie & 81 & 73 & 87 & 91 & 77 & 69 \\
\hline International management & 63 & 46 & 80 & 71 & 54 & 37 \\
\hline Totaal & 54 & 48 & 77 & 81 & 46 & 43 \\
\hline
\end{tabular}

Bron: ROA/WO-Monitor Economie 1997

\section{Aansluiting naar richting}

Pas afgestudeerde economen vinden wel vaak een baan die aansluit bij hun opleidingsrichting. Tevens zijn de verschillen tussen de opleidingsrichtingen wat dit aansluitingsaspect betreft kleiner dan bij de aansluiting naar niveau. lets meer dan driekwart van de economen vindt een baan waarvoor de eigen of een verwante opleidingsrichting werd vereist. Alleen algemeen economen wijken hier enigszins van af: $62 \%$ heeft een baan binnen het eigen vakgebied. De afgestudeerden zelf zijn overigens vaker van mening dat hun baan bij de eigen opleidingsrichting aansluit. Dit kan erop duiden dat de economen in sommige gevallen aan een niet-economische functie een eigen (economische) invulling geven. Ook kan het betekenen dat werkgevers niet altijd een duidelijk beeld hebben van de inhoud van bepaalde opleidingen. 


\section{Aansluiting naar niveau én naar richting}

In totaal blijkt dat iets minder dan de helft van de economen na anderhalf jaar een functie bekleedt die qua richting én qua niveau aansluit bij de gevolgde opleiding. De verschillen tussen de opleidingsrichtingen zijn daarbij echter vrij groot. Deze verschillen worden voornamelijk veroorzaakt door de grote variatie tussen opleidingsrichtingen die optreden bij het aansluitingsaspect niveau. Eén van de drie bestuurlijk informatiekundigen vindt een baan die zowel qua niveau als qua richting aansluit bij de gevolgde opleiding. Econometristen en fiscaal economen vinden relatief vaak een passende baan. Circa driekwart van hen is er in geslaagd een goed aansluitende baan te vinden.

Tabel 3.2

Passende functie, 1995-1997

\begin{tabular}{|c|c|c|c|}
\hline \multirow[t]{2}{*}{ Opleidingsrichting } & \multicolumn{3}{|c|}{$\begin{array}{l}\text { op eigen niveau en } \\
\text { eigen/verwante richting }\end{array}$} \\
\hline & $\begin{array}{c}1995 \\
\%\end{array}$ & $\begin{array}{c}1996 \\
\%\end{array}$ & $\begin{array}{c}1997 \\
\%\end{array}$ \\
\hline Bedrijfskunde & $\mathrm{x}$ & 39 & 43 \\
\hline Bestuurlijke informatiekunde & 45 & 32 & 30 \\
\hline Econometrie & 52 & 50 & 68 \\
\hline Algemene economie & 60 & 48 & 49 \\
\hline Bedrijfseconomie & 51 & 41 & 41 \\
\hline Fiscale economie & 90 & 85 & 77 \\
\hline International management & 61 & 48 & 54 \\
\hline Totaal & 52 & 44 & 46 \\
\hline
\end{tabular}

$\mathrm{X}=$ geen gegevens beschikbaar. De opleiding bedrijfskunde (te studeren aan de Vrije Universiteit en de Universiteit van Amsterdam) is pas vanaf 1996 opgenomen in de WOMonitor Economie. De opleiding Internationale Bedrijfskunde aan de Universiteit Maastricht kent in het studiejaar 1993/1994 nog geen afgestudeerden. De opleiding Bedrijfskunde aan de Erasmus Universiteit Rotterdam valt niet onder de economische faculteit.

Bron: ROA/WO-Monitor Economie 1995-1997

Een vergelijking in de tijd van de aansluiting tussen het gevonden werk en de gevolgde opleiding kan een indicatie geven van de ontwikkeling in arbeidsmarktpositie die een opleiding(srichting) doormaakt. Tabel 3.2 geeft een overzicht van de recente verschuivingen. In deze tabel staat zowel de ontwikkeling van de aansluiting naar niveau als de aansluiting naar richting weergegeven voor de periode 19951997. Voor economen als totale groep lijkt de kans op een passende functie tussen 1995 en 1997 duidelijk afgenomen. Wel zijn er duidelijke verschillen naar opleidingsrichting. Zo vinden bestuurlijk informatiekundigen steeds minder vaak een baan op academisch niveau, terwijl ze in 1997 wel vaker een baan binnen de eigen opleidingsrichting vinden dan in 1995. Voor econometristen is de situatie voor beide aansluitingsaspecten sterk verbeterd sinds 1995 . Voor afgestudeerden international management geldt een duidelijke verbetering in vergelijking met afgelopen jaar. In 1997 doen deze afgestudeerden het bij zowel het vinden van academisch werk als 
het vinden van werk in de eigen opleidingsrichting beter dan de gemiddelde econoom.

Het feit dat er de afgelopen drie jaar een daling heeft plaatsgevonden in het percentage economen dat een passende baan vindt, relativeert overigens ook de daling in het werkloosheidspercentage (zie hoofdstuk 2) enigszins. Blijkbaar betekent een grotere kans op werk niet automatisch een grotere kans op passend werk. In hoofdstuk 4 wordt dieper ingegaan op degenen die momenteel werkzaam zijn op HBO-niveau.

\subsection{Andere kwalitatieve aspecten van het werk}

\section{Arbeidsuren en nevenfuncties}

Zoals blijkt uit tabel 3.3, zijn de meeste economen werkzaam in een full-time baan, dat wil zeggen een baan van ten minste 33 uur per week. Algemeen economen zijn juist iets vaker part-time werkzaam, terwijl fiscalisten en IM'ers vrijwel allemaal een full-time functie bekleden. Verder blijkt dat vrouwen iets vaker een part-time functie hebben dan mannen. Dit geldt voornamelijk voor de opleidingsrichtingen bedrijfskunde, bestuurlijke informatiekunde en algemene economie. Voor alle drie de opleidingsrichtingen geldt dat meer dan $10 \%$ van de afgestudeerde vrouwen anderhalf jaar na afstuderen een part-time functie heeft. Een kleine groep economen heeft naast de hoofdfunctie nog een nevenfunctie. Dit geldt voor $4 \%$ van de economen. Fiscalisten hebben driemaal zo vaak een betaalde nevenfunctie als gemiddeld. Ook bedrijfskundigen bekleden verhoudingsgewijs vaak meer dan één functie.

Tabel 3.3

Arbeidsuren en nevenfuncties

\begin{tabular}{|c|c|c|c|c|}
\hline Opleidingsrichting & $\underset{\%}{\operatorname{man}}$ & $\begin{array}{c}\text { part-time } \\
\text { vrouw } \\
\%\end{array}$ & $\begin{array}{c}\text { totaal } \\
\%\end{array}$ & $\begin{array}{c}\text { nevenfunctie } \\
\%\end{array}$ \\
\hline $\begin{array}{l}\text { Bedrijfskunde } \\
\text { Bestuurlijke informatiekunde } \\
\text { Econometrie } \\
\text { Algemene economie } \\
\text { Bedrijfseconomie } \\
\text { Fiscale economie } \\
\text { International management }\end{array}$ & $\begin{array}{l}0 \\
0 \\
4 \\
6 \\
5 \\
0 \\
0\end{array}$ & $\begin{array}{r}12 \\
17 \\
2 \\
15 \\
8 \\
0 \\
0\end{array}$ & $\begin{array}{l}5 \\
3 \\
4 \\
9 \\
6 \\
0 \\
0\end{array}$ & $\begin{array}{r}8 \\
0 \\
2 \\
6 \\
5 \\
12 \\
3\end{array}$ \\
\hline Totaal & 5 & 8 & 6 & 4 \\
\hline
\end{tabular}

Bron: ROA/WO-Monitor Economie 1997 


\section{Beloning}

Een belangrijk kwalitatief aspect van het werk betreft vanzelfsprekend de beloning. Tabel 3.4 laat zien dat economen die een full-time functie hebben gemiddeld iets meer dan 4.000 gulden bruto per maand verdienen. Bedrijfskundigen en IM'ers verdienen met een beloning rond 4.500 gulden bruto per maand duidelijk meer dan de andere economen. Deze verschillen blijven ook aanwezig wanneer gecorrigeerd wordt voor het aantal gemaakte arbeidsuren. Het gemiddelde bruto uurloon van economen ligt rond de 25 gulden, terwijl bedrijfskundigen en afgestudeerden international management twee respectievelijk één gulden per uur meer verdienen.

De spreiding (standaarddeviatie) van dit loon geeft inzicht in de loonverschillen die er bestaan tussen economen met een zelfde opleidingsachtergrond. Het blijkt dat met name binnen de opleidingsrichting bedrijfseconomie grote loonverschillen bestaan. Kleine loonverschillen zijn er binnen de groepen afgestudeerden bestuurlijk informatiekunde en in iets mindere mate fiscale economie en international management.

Tabel 3.4

Beloning in de hoofdfunctie

\begin{tabular}{lrrr}
\hline Opleidingsrichting & $\begin{array}{r}\text { bruto maand- } \\
\text { loon full-timers } \\
\text { guldens }\end{array}$ & $\begin{array}{r}\text { bruto uurloon } \\
\text { full/parttimers } \\
\text { guldens }\end{array}$ & spreiding \\
\hline Bedrijfskunde & 4.530 & 26,70 & 6,30 \\
Bestuurlijk informatiekunde & 4.170 & 23,90 & 2,80 \\
Econometrie & 4.190 & 24,40 & 6,00 \\
Algemene economie & 4.070 & 23,50 & 6,10 \\
Bedrijfseconomie & 4.240 & 24,60 & 8,40 \\
Fiscale economie & 4.270 & 23,60 & 5,20 \\
International management & 4.420 & 25,60 & 5,80 \\
Totaal & 4.250 & 24,60 & 7,90 \\
\hline
\end{tabular}

Bron: ROA/WO-Monitor Economie 1997

Tabel 3.5 geeft de ontwikkeling van het bruto uurloon in de laatste drie jaar weer. Het blijkt dat de gemiddelde beloning van economen de afgelopen drie jaar jaarlijks met ongeveer een gulden is toegenomen. Dat is procentueel gezien een stijging van ongeveer $5 \%$ per jaar. Dit in tegenstelling tot bijvoorbeeld afgestudeerden van het HBO. Zij zijn er de afgelopen drie jaar wat beloning betreft zelfs licht op achteruit gegaan (zie Allen en Ramaekers, 1998). Het lijkt erop dat de krapte op de arbeidsmarkt voor economen enige opwaartse loondruk veroorzaakt. Vooral de beloning van bedrijfskundigen, econometristen en IM'ers is het afgelopen jaar fors gestegen. Voor deze laatste twee groepen kan deze stijgende beloning samenhangen met de algehele krapte op de arbeidsmarkt, alsmede met het feit dat deze economen steeds vaker een functie op WO-niveau vinden. 
Tabel 3.5

Bruto uurloon in de hoofdfunctie, 1995-1997

\begin{tabular}{lrrr}
\hline Opleidingsrichting & 1995 & 1996 & 1997 \\
\hline Bedrijfskunde & $X$ & 22,20 & 26,70 \\
Bestuurlijke informatiekunde & 22,40 & 23,60 & 23,90 \\
Econometrie & 21,30 & 23,00 & 24,40 \\
Algemene economie & 21,70 & 23,60 & 23,50 \\
Bedrijfseconomie & 22,60 & 23,20 & 24,60 \\
Fiscale economie & 23,60 & 25,90 & 23,60 \\
International management & 22,10 & 22,60 & 25,60 \\
Totaal & 22,40 & 23,30 & 24,60 \\
\hline
\end{tabular}

$\mathrm{X}=$ geen gegevens beschikbaar

Bron: ROA/WO-Monitor Economie 1995-1997

\section{Secundaire arbeidsvoorwaarden}

Loopt de gemiddelde beloning van de afgestudeerde van de onderscheiden opleidingsrichtingen niet zozeer uiteen, waar het de secundaire arbeidsvoorwaarden betreft, bestaan er terdege vrij grote verschillen. De resultaten, gepresenteerd in tabel 3.6, zijn ontleend aan het onderzoek gehouden in 1996. Waarschijnlijk fluctueren de uitkomsten echter niet erg over de jaren. lets meer dan de helft van alle bestuurlijk informatiekundigen heeft de beschikking over een auto van de zaak; bij algemeen economen is dit slechts $7 \%$. Voor de afgestudeerden van de overige richtingen varieert dit tussen de 20 en $30 \%$. Een dertiende maand, winstdeling of eindejaarsuitkering is gemeengoed onder de economen. Ook hier blijven de algemeen economen, maar opvallend genoeg ook de IM'ers achter. In totaal heeft een kwart van de afgestudeerde economen geen van de hier genoemde financiële voordelen in hun huidige functie.

Het feit dat algemeen economen in 1996 minder vaak in aanmerking komen voor de genoemde secundaire arbeidsvoorwaarden kan voor een gedeelte worden verklaard uit het feit dat ze vaker dan de andere economen werkzaam waren in de non-profit sector. Tabel 3.7 geeft hiervan een overzicht ${ }^{3}$. Negen van de tien economen zijn actief in de private sector; voor algemeen economen geldt dit slechts voor driekwart. Wanneer nu de onderverdeling naar sector (profit/non-profit) wordt gemaakt, blijkt dat economen die in de profit-sector werken vaker een extra uitkering krijgen of een auto van de zaak hebben dan economen actief in de non-profit sector (zie ook Van der Velden en Wolbers, 1998).

3. Vanwege de vergelijkbaarheid is ook hier uitgegaan van de resultaten voor 1996. 
Tabel 3.6

Secundaire arbeidsvoorwaarden, 1996

\begin{tabular}{lrrr}
\hline Opleidingsrichting & $\begin{array}{r}\text { auto van } \\
\text { de zaak }\end{array}$ & $\begin{array}{r}\text { 13e maand, } \\
\text { winstdeling en/of } \\
\text { eindejaarsuitkering } \\
\%\end{array}$ & $\begin{array}{r}\text { geen financiële } \\
\text { voordelen }\end{array}$ \\
\hline Bedrijfskunde & 31 & 75 & $\%$ \\
Bestuurlijke informatiekunde & 56 & 79 & 20 \\
Econometrie & 24 & 69 & 10 \\
Algemene economie & 7 & 53 & 44 \\
Bedrijfseconomie & 21 & 72 & 23 \\
Fiscale economie & 30 & 70 & 21 \\
International management & 19 & 55 & 26 \\
Totaal & 22 & 70 & 25 \\
\hline
\end{tabular}

Bron: ROA/WO-Monitor Economie 1996

Tabel 3.7

Percentage werkzaam in de profit-sector en secundaire arbeidsvoorwaarden naar sector, 1996

\begin{tabular}{|c|c|c|c|c|c|}
\hline \multirow[t]{2}{*}{ Opleidingsrichting } & \multirow{2}{*}{$\begin{array}{c}\text { profit- } \\
\text { sector } \\
\%\end{array}$} & \multicolumn{2}{|c|}{$\begin{array}{l}\text { auto van } \\
\text { de zaak }\end{array}$} & \multicolumn{2}{|c|}{$\begin{array}{l}\text { 13e maand, winstdeling } \\
\text { en/of eindejaarsuitkering }\end{array}$} \\
\hline & & $\begin{array}{l}\text { profit } \\
\%\end{array}$ & $\begin{array}{c}\text { non-profit } \\
\%\end{array}$ & $\begin{array}{l}\text { profit } \\
\%\end{array}$ & $\begin{array}{c}\text { non-profit } \\
\%\end{array}$ \\
\hline Bedrijfskunde & 87 & 31 & $x$ & 57 & $x$ \\
\hline Bestuurlijke informatiekunde & 97 & 59 & $x$ & 63 & $x$ \\
\hline Econometrie & 85 & 29 & 0 & 58 & 8 \\
\hline Algemene economie & 74 & 11 & 0 & 43 & 26 \\
\hline Bedrijfseconomie & 91 & 23 & 5 & 53 & 19 \\
\hline Fiscale economie & 88 & 32 & $\mathrm{x}$ & 61 & $\mathrm{X}$ \\
\hline International management & 97 & 21 & $\mathrm{x}$ & 50 & $\mathrm{x}$ \\
\hline Totaal & 89 & 25 & 3 & 53 & 17 \\
\hline
\end{tabular}

$\mathrm{X}=$ te weinig waarnemingen

Bron: ROA/WO-Monitor Economie 1996

\section{Leidinggeven en werkervaring}

Het blijkt dat één op de vijf economen anderhalf jaar na afstuderen een leidinggevende functie heeft (zie tabel 3.8). Bedrijfskundigen zijn verhoudingsgewijs vaak in een leidinggevende functie werkzaam. Econometristen en algemeen economen hebben daarentegen minder vaak een leidinggevende functie dan gemiddeld. Wanneer een econoom een functie met een leidinggevend karakter vervult dan geeft hij of zij gemiddeld genomen aan acht mensen leiding.

Voor het verwerven van een leidinggevende functie is het hebben van werkervaring een pré, zo blijkt uit het rechtergedeelte van tabel 3.8. Economen met werkervaring hebben vaker leidinggevend werk dan economen zonder werkervaring. Dit geldt vooral voor bedrijfskundigen, algemeen economen en degenen die in international 
management zijn afgestudeerd. Bij meer dan de helft van de afgestudeerden van deze studierichtingen die een leidinggevende functie bekleden werd werkervaring vereist bij intrede in de functie.

Tabel 3.8

Leidinggeven en vereiste werkervaring

\begin{tabular}{lrrr}
\hline Opleidingsrichting & leidinggeven & $\begin{array}{r}\text { vereiste werkervaring } \\
\text { wanneer wel leiding- } \\
\text { gevende functie } \\
\%\end{array}$ & $\begin{array}{r}\text { vereiste werkervaring } \\
\text { wanneer geen leiding- } \\
\text { gevende functie } \\
\%\end{array}$ \\
\hline Bedrijfskunde & 29 & 64 & 22 \\
Bestuurlijke informatiekunde & 18 & 0 & 15 \\
Econometrie & 12 & 12 & 9 \\
Algemene economie & 13 & 63 & 21 \\
Bedrijfseconomie & 22 & 39 & 22 \\
Fiscale economie & 21 & 33 & 4 \\
International management & 20 & 37 & 29 \\
Totaal & 20 & 39 & 21 \\
\hline
\end{tabular}

Bron: ROA/WO-Monitor Economie 1997

Pas afgestudeerden kunnen vaak moeilijk voldoen aan de door de werkgever voor de functie benodigde werkervaring, omdat ze slechts recentelijk de arbeidsmarkt hebben betreden. Vaak wordt gewezen op het belang van werk- of bestuurservaring tijdens de studie voor de voorspoedige intrede op de arbeidsmarkt. Daarnaast kan via stage(s) belangrijke ervaring worden opgedaan. Tabel 3.9 geeft een overzicht van relevante werk-, bestuurs- en stage-ervaring die de economen hebben opgedaan tijdens hun studie.

Tabel 3.9

Relevante werkervaring

\begin{tabular}{lrrrr}
\hline Opleidingsrichting & $\begin{array}{r}\text { relevante } \\
\text { werkervaring } \\
\text { tijdens studie } \\
\%\end{array}$ & $\begin{array}{r}\text { bestuurlijke } \\
\text { ervaring }\end{array}$ & $\begin{array}{r}\text { stage } \\
\text { tijdens studie } \\
\%\end{array}$ & $\begin{array}{r}\text { geen van de } \\
\text { gemoemde } \\
\text { ervaringen } \\
\%\end{array}$ \\
\hline Bedrijfskunde & 61 & 71 & 97 & 0 \\
Bestuurlijke informatiekunde & 50 & 44 & 91 & 3 \\
Econometrie & 36 & 51 & 72 & 7 \\
Algemene economie & 51 & 61 & 59 & 12 \\
Bedrijfseconomie & 50 & 55 & 67 & 10 \\
Fiscale economie & 67 & 42 & 64 & 12 \\
International management & 38 & 65 & 76 & 12 \\
Totaal & 50 & 56 & 68 & 10 \\
\hline
\end{tabular}

Bron: ROA/WO-Monitor Economie 1997

Het blijkt dat maar liefst de helft van alle economen tijdens de studie relevante werkervaring heeft opgedaan. Daarnaast heeft nog eens iets meer dan de helft van de 
economen bestuurlijke ervaring opgedaan. Twee van de drie economen heeft bovendien stage gelopen. In totaal blijkt dat slechts $10 \%$ van alle economen geen enkele relevante werkervaring of bestuurservaring heeft opgedaan ten tijde van de studie. Het blijkt overigens dat bedrijfskundigen veel vaker werk- of bestuurservaring hebben dan andere economen. Fiscalisten hebben relatief vaak (relevante) werkervaring opgedaan tijdens hun studie, maar zijn juist minder vaak bestuurlijk actief geweest. 


\section{Economen op de arbeidsmarkt voor HBO'ers}

De groep universitair opgeleide economen die er in de transitiefase van studie naar werk niet in is geslaagd een baan op WO-niveau te bemachtigen is al jaren vrij groot. Ook de aantrekkende werkgelegenheid van de afgelopen jaren heeft daar nagenoeg geen verandering in kunnen brengen. Zoals hoofdstuk 3 heeft laten zien, heeft bijna de helft van alle pas afgestudeerde economen een baan waarvoor strikt genomen geen WO-opleiding is vereist. Dit hoofdstuk probeert een antwoord te geven op de vraag waarom bijna de helft van alle universitaire economen zijn/haar carrière start in een functie die ook met een HBO-diploma zou kunnen worden vervuld. Het antwoord op deze vraag kan tweeledig zijn, enerzijds is het mogelijk dat de groep economen niet homogeen is wat betreft capaciteiten. De ene econoom heeft wellicht minder capaciteiten dan de andere en verliest daardoor de concurrentiestrijd voor een WO-functie. Dit zou kunnen wijzen op een tekort aan beschikbare banen op WO-niveau. Anderzijds zou het kunnen dat er verschillen bestaan tussen banen op HBO- en WO-niveau die kunnen verklaren waarom sommige economen kiezen voor een WO-functie en andere voor een HBO-functie. Wellicht kiezen universitaire economen er bewust voor om de carrière een trapje lager te beginnen, omdat er op dit niveau betere ontplooiingsmogelijkheden zijn. Naast deze twee vragen komen ook de mogelijke gevolgen voor de opleiding van deze substantiële onderbenutting ter sprake. Men mag verwachten dat het oordeel over de universitaire opleiding van economen die terecht zijn gekomen in een HBO-functie afwijkt van die van economen die werkzaam zijn op WO-niveau. Ook wordt getracht de vraag te beantwoorden of een WO-opleiding wel een zinvolle investering is, zeker voor degenen die eerst een HBO-diploma hebben behaald. Eerst geven we echter een beschrijving van de precieze omvang van de groep economen actief op HBOniveau.

Tabel 4.1

Door werkgever vereiste opleidingsniveau

\begin{tabular}{lcccc}
\hline Opleidingsrichtingen & $\begin{array}{r}\text { WO } \\
\%\end{array}$ & $\begin{array}{r}\text { HBO } \\
\%\end{array}$ & $\begin{array}{r}\text { MBO } \\
\%\end{array}$ & $\begin{array}{r}<\text { MBO } \\
\%\end{array}$ \\
\hline Bedrijfskunde & 51 & 46 & 3 & 0 \\
Bestuurlijke Informatiekunde & 35 & 65 & 0 & 0 \\
Econometrie & 77 & 23 & 0 & 0 \\
Algemene economie & 61 & 34 & 3 & 2 \\
Bedrijfseconomie & 49 & 48 & 3 & 0 \\
Fiscale economie & 81 & 19 & 0 & 0 \\
International management & 63 & 31 & 6 & 1 \\
Totaal & 54 & 43 & 2 & \\
\hline
\end{tabular}

Bron: ROA/WO-Monitor Economie 1997 
Tabel 4.1 toont dat het overgrote deel van de economen die niet op universitair niveau werkzaam zijn een functie op HBO-niveau heeft gevonden. Zoals de tabel laat zien zijn het met name bestuurlijk informatiekundigen, bedrijfseconomen en bedrijfskundigen die vaak een baan op HBO-niveau hebben. Deze cijfers worden des te opmerkelijker als gekeken wordt naar het percentage economen dat actief is in een HBO-functie en niet meer verder zoekt naar een andere functie (zie tabel 4.2). Het blijkt dat vier van de vijf economen die werkzaam zijn op HBO-niveau niet meer verder zoeken. Het verschil met degenen die een functie op WO-niveau hebben gevonden is met name bij bedrijfs- en fiscaal economen vrij klein. Ofschoon de afgestudeerden die een baan op WO-niveau hebben minder vaak zoeken naar een andere baan, mag worden geconcludeerd dat het merendeel van de economen die werkzaam zijn in een HBO-functie tevreden is met de huidige baan. Hebben zij zich neergelegd bij het feit dat een baan op universitair niveau niet voor hun is weggelegd of ambiëren zij functies die (formeel) op HBO-niveau worden getypeerd?

Tabel 4.2

Percentage werkzaam op HBO- of WO-niveau dat niet op zoek is naar ander werk

\begin{tabular}{lcc}
\hline Opleidingsrichting & $\begin{array}{c}\text { HBO-niveau } \\
\%\end{array}$ & $\begin{array}{c}\text { WO-niveau } \\
\%\end{array}$ \\
\hline Bedrijfskunde & 83 & 95 \\
Bestuurlijke Informatiekunde & 86 & 100 \\
Econometrie & 80 & 92 \\
Algemene economie & 62 & 86 \\
Bedrijfseconomie & 80 & 83 \\
Fiscale economie & 83 & 86 \\
International management & 77 & 86 \\
Totaal & 79 & \\
\hline
\end{tabular}

Bron: ROA/WO-Monitor Economie 1997

\subsection{Andere mensen?}

Wanneer heterogeniteit tussen de afgestudeerden de oorzaak is van het feit dat bepaalde economen niet in aanmerking komen voor een functie op WO-niveau dan mag verwacht worden dat beide groepen verschillen naar relevante achtergrondkenmerken. Om een beeld te krijgen van deze heterogeniteit tussen afgestudeerden is een regressie-analyse uitgevoerd. De resultaten hiervan staan weergegeven in tabel 4.3. Het blijkt dat economen die de opleiding als te makkelijk beschouwen significant vaker een functie op WO-niveau vinden dan economen die de opleiding niet te makkelijk vonden. Dit wijst er inderdaad op dat de afgestudeerden met de grootste capaciteiten een voorsprong hebben wat betreft het vinden van een baan op WO-niveau.

Een andere indicatie van de capaciteiten vormt de studieduur. In de regressie is de netto studieduur meegenomen. Dit betreft de duur van de studie, gecorrigeerd voor 
eventuele onderbrekingen. Deze netto studieduur heeft nauwelijks effect op de kans dat pas afgestudeerde economen op HBO-niveau, danwel op WO-niveau terechtkomen. De studieduur hoeft echter op zich nog niet zoveel te zeggen over hoe de economen deze studieduur hebben ingekleed. Van economen met hogere capaciteiten mag verwacht worden dat ze naast hun studie allerlei nevenactiviteiten hebben ontplooid. Uit de regressie blijkt dat het opdoen van bestuurlijke ervaring tijdens de studie een grotere kans oplevert op een baan op WO-niveau. Dit geldt ook voor het opdoen van relevante werkervaring tijdens de studie. Een eventueel gevolgde stage daarentegen heeft geen significante invloed op het niveau van de verkregen functie.

Voorts is het opmerkelijk dat afgestudeerde economen die eerst een $\mathrm{HBO}$-opleiding hebben gedaan aanzienlijk vaker uiteindelijk toch in een HBO-functie terechtkomen. Dit kan zowel een weerspiegeling zijn van hun capaciteiten, maar ook kan dit resultaat aangeven dat degenen met een HBO-vooropleiding vaker 'terugvallen' op deze oorspronkelijke opleiding als zij zich aanbieden op de arbeidsmarkt.

Tabel 4.3

Factoren die de kans op WO-functie beïnvloeden (logistische regressie)

\begin{tabular}{lcc}
\hline Onafhankelijke factoren & parameter & $\begin{array}{c}\text { standaard } \\
\text { deviatie }\end{array}$ \\
\hline Constante & $5,16^{\star *}$ & 0,65 \\
WO-opleiding te makkelijk & $0,27^{*}$ & 0,14 \\
Vooropleiding: HBO & $-0,74^{\star \star}$ & 0,21 \\
Netto studieduur & $-0,01$ & 0,00 \\
Bestuurlijke ervaring & $0,78^{\star \star}$ & 0,12 \\
Stage gelopen & 0,11 & 0,13 \\
Relevante werkervaring & $0,44^{\star *}$ & 0,12 \\
Gini-Hirschman-index & $-3,11^{* *}$ & 0,63
\end{tabular}

* significant op 5\%-niveau

** significant op $1 \%$-niveau

Naast de hierboven genoemde aanbod-gerelateerde factoren kan vanzelfsprekend ook de gevolgde opleiding een rol spelen bij de mate waarin men erin slaagt een functie op WO-niveau te verwerven. Verwacht mag worden dat met name de afgestudeerden van opleidingen die veel uitwijkmogelijkheden op WO-niveau bieden relatief vaak ook op WO-niveau werkzaam zijn. In de analyse is daarvoor de GiniHirschman-index meegenomen. Deze index geeft een beeld van de beroepenspreiding en daarmee de uitwijkmogelijkheden die economen op de arbeidsmarkt hebben. De index ligt tussen 0 en 1: hoe groter de index hoe groter de uitwijkmogelijkheden ${ }^{4}$. Het blijkt vreemd genoeg dat relatief veel uitwijkmogelijkheden negatief is

4. Zie voor een gedetailleerde beschrijving van deze index, ROA (1995). 
gerelateerd aan de kans op een WO-functie. Grotere uitwijkmogelijkheden leveren geen hogere, maar juist een lagere kans op een WO-baan op.

Tabel 4.4

Uitwijkmogelijkheden op WO-niveau en percentage werkzaam op WO-niveau of in passende baan

\begin{tabular}{llll}
\hline Opleidingsrichting & $\begin{array}{l}\text { Gini-Hirschman- } \\
\text { index }\end{array}$ & $\begin{array}{l}\text { werkzaam op } \\
\text { WO-niveau } \\
\%\end{array}$ & $\begin{array}{l}\text { passende } \\
\text { baan } \\
\%\end{array}$ \\
\hline Bedrijfskunde & 0,82 & 51 & 43 \\
International management & 0,80 & 63 & 54 \\
Bedrijfseconomie & 0,76 & 49 & 41 \\
Bestuurlijke informatiekunde & 0,74 & 35 & 30 \\
Econometrie & 0,60 & 77 & 49 \\
Algemene economie & 0,55 & 61 & 77 \\
Fiscale economie & 0,17 & & \\
\hline
\end{tabular}

Bron: ROA/WO-Monitor Economie 1997

Tabel 4.4 geeft de Gini-Hirschman-index, het percentage economen dat werkzaam is op WO-niveau en het deel dat een passende baan vindt (een baan op WO-niveau en in de eigen of verwante richting). De combinatie van beide factoren geeft een indicatie van de problemen waarmee de econoom op zoek naar een baan op WO-niveau wordt geconfronteerd. Weinig uitwijkmogelijkheden hoeft geen probleem te zijn als de afgestudeerden die niet nodig hebben, omdat ze een passende functie kunnen vinden (zoals fiscaal economen). Economen die lastig een passende baan vinden, zoals bedrijfskundigen, bestuurlijk informatiekundigen en bedrijfseconomen, hebben goede uitwijkmogelijkheden nodig om toch een baan te kunnen vinden op WO-niveau. Toch lukt het een belangrijk deel van deze economen niet om een baan op WO-niveau te vinden, ondanks het feit dat de gevolgde opleiding betrekkelijk veel mogelijkheden biedt om een baan op WO-niveau te vinden.

\subsection{Andere banen?}

Niet alleen de mogelijkheden op een baan op WO-niveau, maar ook de expliciete wens van de econoom om in een baan werkzaam te zijn die als HBO-niveau wordt gekwalificeerd kan een rol spelen bij het feit dat een grote groep economen werkzaam is op HBO-niveau. Tabel 4.5 geeft een indicatie van de belangrijkste HBO-beroepen waarin pas afgestudeerde economen werkzaam zijn, terwijl ze niet verder zoeken naar ander werk. Het blijkt dat de economen die tevreden zijn met hun huidige $\mathrm{HBO}$-functie vooral werkzaam zijn in beroepen als organisatie-adviseurs en assistent accountants. 
Tabel 4.5

Belangrijkste beroepen op HBO-niveau van degenen die niet op zoek zijn naar ander werk

Beroep $\%$

Organisatie-adviseurs

Assistent accountants 23

Systeemanalisten 12

Technisch systeemanalisten 10

Organisatie deskundigen

31
23
12
10
8

Bron: ROA/WO-Monitor Economie 1997

Beredeneerd kan worden dat iemand voor een HBO-functie kiest als zo'n baan karakteristieken heeft die compenseren voor het feit dat het geen WO-functie betreft. Voorbeelden van dit soort karakteristieken zouden een vaste aanstelling en/of een leidinggevende functie kunnen zijn. Tabel 4.5 geeft deze en enkele andere karakteristieken van HBO-functies en WO-functies weer. Van de economen die een HBOfunctie hebben, zijn slechts diegenen meegenomen die aangeven dat ze niet meer verder zoeken naar een andere functie. Zij zijn blijkbaar tevreden met de gevonden HBO-functie.

Tabel 4.6

Baankenmerken in functies op HBO en WO-niveau

\begin{tabular}{lcr}
\hline Baankenmerken & HBO-niveau & WO-niveau \\
\hline & 72 & 84 \\
eigen opleidingsrichting** (\%) & 68 & 72 \\
vaste aanstelling (\%) & 6 & 4 \\
onvrijwillige deeltijd (\%) & 20 & 21 \\
leidinggevende functie (\%) & 4.140 & 4.370 \\
huidige bruto maandinkomen* (guldens) & &
\end{tabular}

* significant op 5\%-niveau

** significant op $1 \%$-niveau

Bron: ROA/WO-Monitor Economie 1997

Economen die op WO-niveau werkzaam zijn, zijn significant vaker actief in de eigen opleidingsrichting. Ook hebben ze iets vaker een vaste aanstelling dan economen met een HBO-functie, alhoewel dit verschil niet significant is. Economen die werkzaam zijn op HBO-niveau hebben iets vaker onvrijwillig een deeltijdaanstelling. Wanneer wordt gekeken naar de mate waarin afgestudeerde economen een leidinggevende functie weten te verwerven blijken er nauwelijks verschillen te zijn tussen diegenen die op HBO- en degenen die op WO-niveau werkzaam zijn. De economen ten slotte die actief zijn op WO-niveau verdienen significant meer dan de economen die naar eigen tevredenheid actief zijn op HBO-niveau. Er lijkt derhalve geen sprake te zijn van compenserende factoren die het aanvaarden van banen op HBO-niveau verklaren. 
Pas afgestudeerde economen kunnen echter ook een $\mathrm{HBO}-$ baan verkiezen boven een WO-baan, omdat ze verwachten op langere termijn beter af te zijn met die HBObaan. Deze toekomstverwachtingen komen uiteraard niet tot uiting in de transitiefase. De verschillen in toekomstverwachtingen tussen economen actief op HBO-niveau en economen actief op WO-niveau staan weergegeven in tabel 4.7. Het gaat hier om de verwachtingen die de pas afgestudeerden zelf hebben. Ook in deze tabel zijn van de economen die op HBO-niveau werkzaam zijn alleen degenen die tevreden zijn over hun HBO-functie meegenomen.

De verschillen in promotieverwachtingen zijn in het algemeen erg klein. Ongeveer de helft van de economen verwacht binnen een jaar naar een hogere functie door te stromen, maar dat geldt voor zowel economen op HBO-niveau als voor economen op WO-niveau. Wat betreft de ontwikkelingsmogelijkheden binnen de huidige functie zijn de verschillen tussen economen met een HBO-baan en economen met een WObaan ook verwaarloosbaar klein. Van beide groepen verwacht ongeveer $80 \%$ ook over vijf jaar nog in het eigen vakgebied werkzaam te zijn. Het feit dat beide groepen ongeveer dezelfde toekomstverwachtingen hebben, duidt erop dat het verschil in carrière-ontwikkeling niet kleiner zal worden. Dit blijkt ook uit de verwachte beloning over vijf jaar. De economen die momenteel reeds op WO-niveau actief zijn, verwachten aanzienlijk meer te gaan verdienen dan degenen die op HBO-niveau werkzaam zijn. Het lijkt er dan ook sterk op dat de economen actief op HBO-niveau niet meer verwachten dat ze de nu opgelopen achterstand ten opzichte van economen werkzaam op WO-niveau nog zullen inlopen.

Tabel 4.7

Toekomstperspectieven in functies op HBO- en WO-niveau

\begin{tabular}{lcc}
\hline Toekomstperspectief & HBO-niveau & WO-niveau \\
\hline Verwacht promotie binnen één jaar (\%) & 53 & 50 \\
Ontwikkelingsmogelijkheden (\%) & 95 & 96 \\
Werkzaam in eigen vakgebied over vijf jaar (\%) $_{\text {Bruto maandloon over vijf jaar (guldens) }}^{\star \star}$ & 84 & 82 \\
& 6.860 & 7.680 \\
\hline
\end{tabular}

** het verschil is significant op 1\%-niveau

Bron: ROA/WO-Monitor Economie 1997

De mogelijkheid dat economen bewust kiezen voor een $\mathrm{HBO}$-functie, omdat er compenserende verschillen zijn tussen functies op HBO-niveau en op WO-niveau vindt geen ondersteuning in tabel 4.6 en 4.7 en lijkt dan ook geen belangrijke reden die kan verklaren waarom economen op HBO-niveau terechtkomen. De vraag blijft echter waarom in een periode met zeer lage werkloosheid een groot deel van de pas afgestudeerde economen op HBO-niveau werkzaam is en dat bovendien de meesten van hen niet op zoek zijn naar een andere baan. De verklaring kan wellicht worden gevonden in het feit dat voor een groot aantal functies een HBO- of WO- 
opleiding wordt gevraagd. Formeel worden deze banen als HBO-niveau gekwalificeerd. $\mathrm{Er}$ is met andere woorden voor economisch opgeleiden sprake van een breed arbeidsmarktdomein waarbij er substitutiemogelijkheden zijn tussen HBO'ers en academici.

\subsection{Universitaire studie na HBO-opleiding: zinvolle investering?}

Ondanks het feit dat veel universitaire economen geen baan vinden op WO-niveau zijn er toch veel HBO-afgestudeerden die kiezen voor een WO-opleiding economie om pas daarna een baan te gaan zoeken. Is dit gezien het voorgaande eigenlijk wel een logische stap? Studenten die een HBO-opleiding hebben afgerond staan voor de keuze: zij kunnen besluiten de arbeidsmarkt te betreden of zij kunnen er voor kiezen om een WO-opleiding te gaan volgen en zich pas dan aan te bieden op de arbeidsmarkt. Economisch opgeleide HBO'ers zullen de tweede keuze maken als dat hun kans op een WO-baan vergroot.

Uit de logistische regressie in tabel 4.3 bleek al dat de economen met een HBOvooropleiding ten opzichte van economen die het VWO als vooropleiding hebben minder vaak een baan op WO-niveau vinden. $\mathrm{Er}$ is een substantiële groep WO-economen met een $\mathrm{HBO}$-achtergrond die een baan hebben gevonden op HBO-niveau $(59 \%)$. Voor deze economen lijkt de investering die ze gedaan hebben door na afronding van de $\mathrm{HBO}$-opleiding niet toe te treden tot de arbeidsmarkt maar verder te gaan studeren op WO-niveau geen zinvolle investering te zijn geweest. Wanneer echter naar de beloning van deze economen wordt gekeken dan blijkt de universitaire economie-opleiding toch een belangrijke meerwaarde te hebben.

Tabel 4.8 geeft een overzicht van de resultaten van een regressie-analyse van de beloningen van $\mathrm{HBO}-e c o n o m e n$ en WO-economen met een $\mathrm{HBO}$-achtergrond. De $\mathrm{HBO}-$ economen werkzaam op HBO-niveau vormen hier de referentiecategorie. Het blijkt dat WO-economen die besloten hebben om na afronding van een HBO-opleiding ook nog een WO-opleiding af te ronden, maar uiteindelijk toch op een HBOfunctie terecht zijn gekomen, zo'n $12 \%$ meer verdienen dan HBO-economen met een $\mathrm{HBO}$-functie ${ }^{5}$. Hieruit blijkt dat de overstap van HBO-opleiding naar WO-opleiding voor een $\mathrm{HBO}-$-econoom een hoog rendement oplevert. Overigens verdienen economen werkzaam in een WO-functie $21 \%$ meer dan de $\mathrm{HBO}$-economen in HBOfuncties.

Eén van de controlevariabelen is de vooropleiding die de HBO- en WO-economen hebben gevolgd voordat ze begonnen aan de $\mathrm{HBO}$-opleiding. Deze factor is meegenomen om te corrigeren voor het feit dat de HBO-economen die besluiten een

5. In deze regressie is de logaritme van het loon gebruikt. Om de coëfficiënten als percentages te kunnen lezen moet de e-macht worden genomen. 
WO-opleiding te gaan volgen wellicht over meer capaciteiten beschikken dan de HBO-economen die besluiten geen WO-opleiding te gaan volgen. Als voor deze laatste groep geldt dat de HBO-opleiding gezien hun capaciteiten het hoogst haalbare opleidingsniveau is dan hebben zij helemaal geen keuze tussen doorstuderen of werk zoeken. We verwachten dat met name de economen die zijn doorgestroomd vanuit het VWO meer capaciteiten hebben. Dat blijkt niet het geval: de vooropleiding heeft geen significant effect op het bruto maandloon.

Tabel 4.8

Regressie van het bruto maandloon van $\mathrm{HBO}-$ economen en WO-economen met een $\mathrm{HBO}$ vooropleiding

\begin{tabular}{lcc}
\hline Onafhankelijke factoren & coëfficiënt & verschil \\
\hline & & \\
constante & $2,30^{\star *}$ & \\
& referentie & $-7 \%$ \\
HBO'er op HBO-functie & $-0,07^{\star \star}$ & $12 \%$ \\
HBO'er op MBO-functie & 0,04 & $21 \%$ \\
HBO'er op WO-functie & $0,11^{\star \star}$ & \\
WO'er op HBO-functie & $0,19^{\star \star}$ & $3 \%$ \\
WO'er op WO-functie & & \\
Controle variabelen: & & \\
Leeftijd & $0,03^{\star \star}$ & \\
Vooropleiding voor HBO: VWO & 0,02 & \\
\end{tabular}

** significant op 1\%-niveau

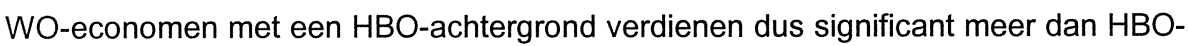
economen, ook wanneer beiden actief zijn in een HBO-functie. Wellicht zijn er nog andere karakteristieken van de HBO-functie die de investering in een WO-opleiding voor een $\mathrm{HBO}-$ econoom lonend maken. Wellicht is een werkgever eerder geneigd om een WO-econoom aan te nemen op een HBO-functie dan een HBO-econoom. De investering in een WO-opleiding zou zodoende de kans op een baan op HBOniveau verhogen. Dit argument zou kunnen blijken uit de eisen die HBO-werkgevers stellen aan sollicitanten. Een van die eisen is vereiste werkervaring. Werkgevers stellen echter geen zwaardere eisen aan HBO-economen dan aan WO-economen, zoals blijkt uit tabel 4.9. De werkgever kan zijn voorkeur voor een WO-econoom ook laten blijken uit de aard van het arbeidscontract dat hij zijn werknemer aanbiedt. Als de werkgever een voorkeur heeft voor een WO-econoom zal hij sneller geneigd zijn hem een vast contract te bieden. Dit blijkt eveneens niet het geval te zijn, zoals tabel 4.9 toont. Ook is het mogelijk dat de HBO-werkgever de aangeboden functie opwaardeert wanneer hij een WO-econoom aanstelt. Dit zou kunnen blijken uit een leidinggevend karakter van de functie en/of de ontplooiingsmogelijkheden in de functie. Ook hier zijn de verschillen tussen HBO-economen en WO-economen niet significant. 
Tabel 4.9

Functie-eisen en functie-invulling van $\mathrm{HBO}$-functie

Functies op HBO-niveau bezet door:

HBO-econoom

$\%$

$34 \quad 37$

ereiste werkervaring

Vaste baan

66

Invulling functie:

Leidinggeven

Ontplooiingsmogelijkheden

22

92

WO-econoom (met HBO-achtergrond)

Bron: ROA/WO-Monitor Economie 1997

\subsection{Gevolgen voor het curriculum?}

Het feit dat ongeveer de helft van de economen niet op academisch, maar op HBOniveau werkzaam is, heeft wellicht gevolgen voor de manier waarop zij terugkijken op hun opleiding. Tabel 4.10 geeft een overzicht van de opleidingskeuze die de economen gemaakt zouden hebben op basis van de kennis die ze achteraf hebben. Men mag verwachten dat universitaire economen die op HBO-niveau terecht zijn gekomen minder tevreden zullen zijn over de destijds gemaakte keuze dan economen die wel een baan op WO-niveau hebben verworven. Uit tabel 4.10 blijkt dat dit inderdaad het geval is, alhoewel de verschillen niet groot zijn. Economen die op HBOniveau werkzaam zijn zouden iets minder vaak opnieuw hun universitaire economieopleiding kiezen. Deze kleine groep zou liever óf een economisch gerichte opleiding binnen het HBO hebben gestudeerd óf een academische opleiding in een andere dan de economische richting. Duidelijk blijkt echter dat de overgrote meerderheid van de economen die een functie op HBO-niveau bekleden achteraf bezien opnieuw de universitaire opleiding zou gaan volgen.

Tabel 4.10

Keuze achteraf naar niveau van de functie

\begin{tabular}{lcc}
\hline Keuze achteraf & $\begin{array}{c}\text { HBO-niveau } \\
\%\end{array}$ & $\begin{array}{c}\text { WO-niveau } \\
\%\end{array}$ \\
\hline WO economie & 86 & 92 \\
HBO economie & 3 & 1 \\
WO anders & 9 & 7 \\
Rest & 1 & 1 \\
\hline
\end{tabular}

Bron: ROA/WO-Monitor Economie 1997 
Het feit dat zo'n grote groep universitaire economen actief is op een HBO-functie heeft mogelijk ook gevolgen voor de inrichting van het curriculum. Wellicht wijten degenen die op HBO-niveau werkzaam zijn dit voor een deel aan de opleiding en zou volgens hen aan bepaalde onderdelen meer aandacht moeten worden besteed. Tabel 4.11 geeft hiervan een overzicht. Om het verschil te accentueren is in tabel 4.11 wederom een onderscheid gemaakt tussen degenen die werkzaam zijn op HBO-niveau en degenen die een functie op WO-niveau bekleden. Alleen wanneer het verschil op de afzonderlijke onderdelen meer dan $5 \%$-punten bedraagt wordt het hier vermeld. De hier genoemde facetten van het curriculum kunnen in vier groepen worden ingedeeld, te weten kennis en technieken, vaardigheden, houdingsaspecten en internationalisering.

Tabel 4.11

Aspecten van het curriculum waaraan meer aandacht zou moeten worden besteed naar niveau van de functie (alleen verschillen meer dan $5 \%$ punten)

\begin{tabular}{|c|c|c|c|}
\hline Aspecten & $\begin{array}{l}\mathrm{HBO} \\
\%\end{array}$ & $\begin{array}{l}\text { WO } \\
\%\end{array}$ & $\begin{array}{l}\text { verschil } \\
\% \text {-punten }\end{array}$ \\
\hline Kennis en technieken: & 31 & 34 & -3 \\
\hline Vakspecifieke methoden en technieken & 23 & 30 & -7 \\
\hline Inzicht in bedrijfsvoering & 26 & 31 & -5 \\
\hline Vaardigheden: & 35 & 36 & -1 \\
\hline Analytische en diagnostische onderzoeksvaardigheden & 20 & 33 & -13 \\
\hline Kwantitatieve onderzoeksvaardigheden & 16 & 24 & -8 \\
\hline Schriftelijke presentatie, schrijfvaardigheid & 50 & 59 & -9 \\
\hline Onderhandelingstechnische en commerciële vaardigheden & 66 & 60 & +6 \\
\hline Plannen, coördineren en organiseren van activiteiten & 42 & 34 & +8 \\
\hline Houdingsaspecten: & 24 & 24 & 0 \\
\hline \multicolumn{4}{|l|}{ - } \\
\hline Internationalisering: & 25 & 36 & -11 \\
\hline Internationale studie-ervaring & 19 & 30 & -11 \\
\hline Internationale werkervaring & 22 & 31 & -9 \\
\hline $\begin{array}{l}\text { Taalvaardigheid (actieve en passieve beheersing van } \\
\text { vreemde talen) }\end{array}$ & 36 & 48 & -12 \\
\hline
\end{tabular}

Bron: ROA/WO-Monitor Economie 1997

De verschillen treden vooral op bij de aspecten vaardigheden, internationalisering en in iets mindere mate bij kennis en technieken. Economen werkend op WO-niveau willen meer aandacht tijdens de studie voor onderzoeksvaardigheden, schrijfvaardigheden en kennis van methoden en technieken, terwijl economen werkend op HBOniveau juist meer aandacht zouden willen hebben voor onderhandelingstechnische en commerciële vaardigheden en het organiseren van activiteiten. Internationale er- 
varingen tijdens de studie worden door economen actief op WO-niveau vaker belangrijker gevonden dan door economen actief op HBO-niveau. Blijkbaar komen economen op WO-niveau vaker in aanraking met vreemde talen dan economen actief op HBO-niveau.

De hierboven genoemde aspecten hoeven niet persé de belangrijkste aandachtspunten te zijn die economen aanstippen. Het zijn alleen de aspecten waarover de meningen van de WO-economen die op HBO-niveau dan wel WO-niveau zijn terecht gekomen uiteenlopen. Daarom staan in tabel 4.12 de tien belangrijkste aspecten die volgens afgestudeerden meer aandacht tijdens de studie zouden moeten krijgen. Opvallend is dat dit dezelfde tien aandachtspunten zijn die het afgelopen jaar in het onderzoek naar voren zijn gekomen (zie Ramaekers, 1997). Dit kan een aanwijzing zijn voor structurele tekortkomingen in het curriculum en de richting van mogelijke toekomstige aanpassingen daarvan.

Tabel 4.12

Belangrijkste aandachtspunten waaraan meer aandacht zou moeten worden besteed naar niveau van de functie

\begin{tabular}{lccc}
\hline Aspecten & HBO & WO \\
& $\%$ & $\begin{array}{r}\text { totaal } \\
\%\end{array}$ \\
\hline & & & 65 \\
Mondelinge presentatie, spreekvaardigheid & 63 & 65 & 65 \\
Onderhandelingstechnische en commerc. vaardigheden & 66 & 60 & 62 \\
Inzicht in informatie-\&communicatietechnologie & 58 & 55 & 57 \\
Schriftelijke presentatie, schrijfvaardigheid & 50 & 59 & 55 \\
Toepassen (theoretische) kennis en technieken in praktijk & 49 & 48 & 48 \\
Taalvaardigheid (beheersing vreemde talen) & 36 & 48 & 43 \\
Recente ontwikkelingen vakgebied & 41 & 45 & 43 \\
Contactuele vaardigheden & 44 & 39 & 41 \\
Plannen, coördineren en organiseren van activiteiten & 42 & 34 & 37 \\
Initiatief \& creativiteit & 35 & 35 & 35 \\
\end{tabular}




\section{Literatuur}

Allen, J.P., G.W.M. Ramaekers (1998), De arbeidsmarktpositie van afgestudeerden van het hoger beroepsonderwijs. HBO-Monitor 1997, Voorlichtingsdienst HBO-Raad, Den Haag.

Borghans, L., A. de Grip, R. Dekker, A. Matheeuwsen, W. Smits, E. Willems (1995), Methodiek van het Informatiesysteem Onderwijs-Arbeidsmarkt 1995, Working Paper, ROA-W-1995/3.

Linden, van der A. en R. Van der Velden (1998), Effects of the initial start on the labour market on the future labour market position: dealing with unobserved heterogeniety, nog te verschijnen.

Meager, N. en H. Metcalf (1987), Recruitment of the Long Term Unemployed, Institute of Manpower Studies, IMS Report no. 138.

Mortensen, D.T. (1986), Job Search and Labor Market Analysis, in: O.C. Ashenfelter and R. Layard (eds.), Handbook of Labor Economics, volume 2.

Ramaekers, G.W.M. (1997), WO-Monitor economie 1996, Basismeting cohort '95, ROA-R1997/4, Maastricht.

Ramaekers, G.W.M. (1996), WO-Monitor economie 1995, Basismeting cohort '94, ROA-R1996/15, Maastricht.

ROA (1998), Schoolverlaters tussen onderwijs en arbeidsmarkt 1997, ROA-R-1998/5, Maastricht.

Velden, R.K.W. van der, M.H.J. Wolbers (1998), Aanvangssalarissen van schoolverlaters werkzaam in de overheidssector, Ministerie van Binnenlandse Zaken, Den Haag.

Wolbers, M.H.J. (1998), Diploma-inflatie en verdringing op de arbeidsmarkt. Een studie naar ontwikkelingen in de opbrengsten van diploma's in Nederland, Thesis, Amsterdam. 


\section{Bijlage 1 Bepaling van 'on-the-job' en 'off-the-job' zoekgedrag}

Tot 'on-the-job' zoekgedrag worden alle maanden gerekend die een respondent heeft gewerkt tussen het moment van afstuderen en het enquête-moment bij (een) vorige werkgever(s) (als hij nu ander werk heeft) of bij alle vorige werkgevers inclusief de laatste werkgever (als hij nu werkloos is). Geeft de respondent bovendien aan dat hij, ondanks dat hij op het enquêtemoment werk heeft, toch nog zoekt naar ander werk, dan tellen ook het aantal maanden actief in de huidige functie mee als 'on-the-job'-zoekgedrag.

Voorbeeld (zie schema 1): Stel een respondent studeert af in januari en wordt geënquêteerd in december. De eerste twee maanden is hij werkloos, vervolgens vindt hij in maart een baan (werkgever 1). In september verruilt hij deze functie voor een andere functie (werkgever 2). In december is de respondent nog steeds actief voor werkgever 2 .

Schema 1

\begin{tabular}{|c|c|c|c|c|c|c|c|c|c|c|c|c|}
\hline $\begin{array}{l}\text { maats. } \\
\text { positie }\end{array}$ & $\begin{array}{l}\text { jan } \\
\text { wl }\end{array}$ & $\begin{array}{l}\text { feb } \\
w l\end{array}$ & $\begin{array}{l}\mathrm{mrt} \\
\mathrm{w} 1\end{array}$ & $\begin{array}{l}\text { apr } \\
\text { w1 }\end{array}$ & $\begin{array}{l}\text { mei } \\
\text { w1 }\end{array}$ & $\begin{array}{l}\text { jun } \\
\text { w1 }\end{array}$ & $\begin{array}{l}\text { jul } \\
\text { w1 }\end{array}$ & $\begin{array}{l}\text { aug } \\
\text { w1 }\end{array}$ & $\begin{array}{l}\text { sep } \\
\text { w2 }\end{array}$ & $\begin{array}{l}\text { okt } \\
\text { w2 }\end{array}$ & $\begin{array}{l}\text { nov } \\
\text { w2 }\end{array}$ & $\begin{array}{l}\text { dec } \\
\text { w2 }\end{array}$ \\
\hline $\begin{array}{l}\text { wl= wer } \\
\text { w1 =eers } \\
\text { w2=twe }\end{array}$ & werk & $\begin{array}{l}\text { ver } \\
\text { ever }\end{array}$ & & & & & & & & & & \\
\hline
\end{tabular}

De zoektijd kan nu als volgt worden onderverdeeld in 'on-the-job' en off-the-job'zoekgedrag. Het aantal maanden dat deze persoon 'off-the-job' heeft gezocht, bedraagt 2 maanden. Het aantal maanden dat deze persoon 'on-the-job' heeft gezocht, is afhankelijk van zijn huidige status. Geeft de persoon aan dat hij nog steeds zoekt naar een andere werkomgeving dan gelden ook de maanden dat hij bij werkgever 2 heeft gewerkt als zoekmaanden en wel 'on-the-job' gezocht. Geeft de persoon aan niet meer verder te zoeken naar werk op het enquêtemoment dan heeft de persoon zijn zoekproces beëindigd vanaf het moment dat hij in dienst trad bij de huidige werkgever. Het 'on-the-job'-zoekgedrag bestaat dan slechts uit de maanden die hij bij de eerste werkgever heeft gewerkt ( 6 maanden).

In de enquête is niet expliciet aan de afgestudeerde gevraagd in welke maand naar werk werd gezocht. Daarom is verondersteld dat als een afgestudeerde baan $A$ inruilt voor baan $B$, hij de gehele periode die hij in baan $A$ actief was, gezocht heeft naar ander werk (dat hij uiteindelijk ook gevonden heeft (baan B)). Het kan echter ook zijn dat de afgestudeerde pas na een bepaalde periode actief te zijn in baan A is gaan zoeken naar ander werk. In dit geval is hij dus niet de gehele periode dat hij actief geweest is in baan A zoekende geweest naar ander werk. Omdat wij hier wel 
de gehele periode(s) bij (de) vorige werkgever(s) kwalificeren als 'on-the-job' zoekgedrag moet het hier gepresenteerde aantal maanden 'on-the-job' zoekgedrag gezien worden als het maximale aantal maanden dat de afgestudeerde in de eerste anderhalf jaar na afstuderen vanuit een functie naar werk heeft gezocht. 